\title{
Mercury and halogen emissions from Masaya and Telica volcanoes, Nicaragua
}

\author{
M. L. I. Witt, ${ }^{1}$ T. A. Mather, ${ }^{1}$ D. M. Pyle, ${ }^{1}$ A. Aiuppa, ${ }^{2,3}$ E. Bagnato, ${ }^{2}$ and V. I. Tsanev ${ }^{4}$ \\ Received 25 September 2007; revised 6 December 2007; accepted 17 March 2008; published 13 June 2008.
}

[1] We report measurements of $\mathrm{Hg}, \mathrm{SO}_{2}$, and halogens $(\mathrm{HCl}, \mathrm{HBr}, \mathrm{HI})$ in volcanic gases from Masaya volcano, Nicaragua, and gaseous $\mathrm{SO}_{2}$ and halogens from Telica volcano, Nicaragua. Mercury measurements were made with a Lumex 915+ portable mercury vapor analyzer and gold traps, while halogens, $\mathrm{CO}_{2}$ and $\mathrm{S}$ species were monitored with a portable multi gas sensor and filter packs. Lumex $\mathrm{Hg}$ concentrations in the plume were consistently above background and ranged up to $350 \mathrm{ng} \mathrm{m}{ }^{-3} . \mathrm{Hg} / \mathrm{SO}_{2}$ mass ratios measured with the real-time instruments ranged from $1.1 \times 10^{-7}$ to $3.5 \times$ $10^{-5}$ (mean $2 \times 10^{-5}$ ). Total gaseous mercury (TGM) concentrations measured by gold trap ranged from 100 to $225 \mathrm{ng} \mathrm{m}^{-3}$. Reactive gaseous mercury accounted for $1 \%$ of TGM, while particulate mercury was $5 \%$ of the TGM. Field measurements of Masaya's $\mathrm{SO}_{2}$ flux, combined with the $\mathrm{Hg} / \mathrm{SO}_{2}$ ratio, indicate a $\mathrm{Hg}$ flux from Masaya of $7.2 \mathrm{Mg} \mathrm{a}^{-1}$. At Masaya's low temperature fumaroles, $\mathrm{Hg} / \mathrm{CO}_{2}$ mass ratios were consistently around $2 \times 10^{-8}$, lower than observed in the main vent $\left(\mathrm{Hg} / \mathrm{CO}_{2} \sim 10^{-7}\right)$. Low-temperature fumarole $\mathrm{Hg}$ fluxes from Masaya are insignificant $\left(\sim 150 \mathrm{~g} \mathrm{a}^{-1}\right)$.

Ratios of S, C and halogen species were also measured at Masaya and Telica volcanoes. $\mathrm{CO}_{2} / \mathrm{SO}_{2}$ ratios at Masaya ranged from 2.8 to 3.9 , comparable to previously published values. At Masaya molar $\mathrm{Br} / \mathrm{SO}_{2}$ was $3 \times 10^{-4}$ and $\mathrm{I}_{\mathrm{SO}}$ was $2 \times 10^{-5}$, suggesting fluxes of $0.2-0.5 \mathrm{Mg} \mathrm{HBr} \mathrm{d}^{-1}$ and $0.02-0.05 \mathrm{Mg} \mathrm{HI} \mathrm{d}^{-1}$. At Telica the $\mathrm{Br} / \mathrm{SO}_{2}$ ratio was also $3 \times 10^{-4}$ and the $\mathrm{I} / \mathrm{SO}_{2}$ ratio was $5.8 \times 10^{-5}$, with corresponding fluxes of $0.2 \mathrm{Mg} \mathrm{HBr} \mathrm{d}^{-1}$ and $0.06 \mathrm{Mg} \mathrm{HI} \mathrm{d}^{-1}$. Gases at both volcanoes are enriched in I relative to $\mathrm{Br}$ and $\mathrm{Cl}$, compared to gases from volcanoes elsewhere.

Citation: Witt, M. L. I., T. A. Mather, D. M. Pyle, A. Aiuppa, E. Bagnato, and V. I. Tsanev (2008), Mercury and halogen emissions from Masaya and Telica volcanoes, Nicaragua, J. Geophys. Res., 113, B06203, doi:10.1029/2007JB005401.

\section{Introduction}

[2] High-temperature emissions from persistently degassing volcanoes are a known source of trace metal emissions to the atmosphere [Aiuppa et al., 2003; Hinkley et al., 1999; Mather et al., 2003; Nriagu, 1989]. These metal emissions may have important environmental consequences, with evidence for water, soils, rock coatings, and vegetation showing elevated metal concentrations near volcanoes [e.g., Allard et al., 2000; Fulignati et al., 2006; Giammanco et al., 1998; Varrica et al., 2000; Watt et al., 2007]. However, volcanogenic trace volatile metal fluxes are poorly constrained and there is an almost complete absence of data on the factors (whether magma composition, eruptive temperature, or volcanic gas composition) that influence metal degassing rates at different volcanoes.

\footnotetext{
${ }^{1}$ Department of Earth Sciences, University of Oxford, Oxford, UK.

${ }^{2}$ Dipartimento di Chimica e Fisica della Terra ed Applicazioni alle Georisorse e ai Rischi Naturali, Università di Palermo, Palermo, Italy.

${ }^{3}$ Sezione di Palermo, Istituto Nazionale di Geofisica e Vulcanologia, Palermo, Italy.

${ }^{4}$ Department of Geography, University of Cambridge, Cambridge, UK.
}

Copyright 2008 by the American Geophysical Union. 0148-0227/08/2007JB005401\$09.00
[3] Mercury is of particular interest since it is a toxic volatile metal found at elevated concentrations in remote regions of the world [Fitzgerald et al., 1998; Morel et al., 1998]. Natural sources of mercury include soils, forests, oceans, and volcanoes [Schroeder and Munthe, 1998]. The concentration of mercury in the atmosphere has been perturbed by recent anthropogenic activities, including mining, coal burning, and waste incineration [Pacyna and Pacyna, 2002]. Atmospheric mercury exists predominantly as gaseous elemental mercury $(\operatorname{Hg}(0) ; \mathrm{GEM})$, which, as a relatively unreactive gas with low solubility, is inefficiently removed by precipitation, leading to an atmospheric lifetime of ca. 0.5-2 years [Lindqvist and Rodhe, 1985; Slemr et al., 1985]. This is in contrast to other metals, which tend to be found in the particle phase and have atmospheric lifetimes of days [Schroeder and Munthe, 1998]. The long atmospheric lifetime means that $\operatorname{Hg}(0)$ can be transported globally, away from its initial source.

[4] A fraction of atmospheric mercury may exist as fine particulate mercury $\left(\mathrm{Hg}_{\mathrm{p}}\right)$ or as reactive gaseous mercury $\left(\mathrm{Hg}^{2+}, \mathrm{RGM}\right)$. Major RGM species include $\mathrm{HgCl}_{2}$, $\mathrm{Hg}(\mathrm{OH})_{2}$ and other mercury halides [Lindberg and Stratton, 1998]. As RGM is more water soluble than GEM, it is the form of $\mathrm{Hg}$ most readily scavenged by rain [Jitaru and 
Adams, 2004] leading to an atmospheric lifetime of days to weeks [Munthe et al., 2001]. Background concentrations of particulate $\mathrm{Hg}$ are thought to be low [Slemr et al., 1985], although close to emission point sources this proportion may increase. Once deposited to waters, biological processes convert relatively inert elemental $\mathrm{Hg}$ into toxic methylated forms [Ullrich et al., 2001] which are lipid soluble and bioaccumulate in the food chain [Bloom, 1992; Jonnalagadda and Rao, 1993; Mason et al., 1995; Morel et al., 1998].

[5] While there is now unequivocal evidence that mercury is present in volcanic emissions [e.g., Bagnato et al., 2007; Varekamp and Buseck, 1981], there remains considerable uncertainty over the quantity of volcanic $\mathrm{Hg}$ emissions, the speciation of these emissions, and their significance to the global natural mercury budget [Pyle and Mather, 2003]. There is also, as yet, only a poor understanding of the partitioning of volcanic mercury fluxes between hightemperature vents and lower-temperature fumaroles and geothermal fields.

[6] Here we present the first measurements of the flux and speciation of $\mathrm{Hg}$ from Masaya volcano in Nicaragua, augmented with new measurements of $\mathrm{Br}$, I, and other volatile species in the plumes from Masaya and Telica volcanoes. We discuss the implications for global volcanic emissions of $\mathrm{Hg}$ and the origins of $\mathrm{Br}$ and $\mathrm{I}$ in volcanic plumes.

\section{Methods}

\subsection{Sampling Locations}

[7] Masaya $\left(11.984^{\circ} \mathrm{N}, 86.161^{\circ} \mathrm{W}\right.$, summit elevation $\left.635 \mathrm{~m}\right)$ is a basaltic shield volcano in Nicaragua (Figure 1a), characterized by extended degassing episodes from the main pit crater [Stoiber et al., 1986]. The current degassing episode began in 1993, and sustained $\mathrm{SO}_{2}$ emissions from the Santiago crater since that time have varied from $\sim 4.5$ to $\sim 21 \mathrm{~kg} \mathrm{~s}^{-1}$ ) [Delmelle et al., 1999; Mather et al., 2006; Rymer et al., 1998], leading to significant environmental impacts downwind from the volcano [Delmelle et al., 2002].

[8] Daytime measurements were made between 23 February and 6 March 2006 at Masaya, Nicaragua. Measurements were made at the crater rim, in the plume from the active vents of Santiago crater at two sites: (1) at Sapper car park to the south and (2) on the upper edge of Nindiri crater to the northwest (Figure 1b). Measurements were also carried out at fumaroles located on the upper edge of Nindiri crater and at the nearby Cerro Comalito (Figure 1b).

[9] Measurements were also made at Telica volcano, a basaltic andesitic stratovolcano located north of Masaya $\left(12.602^{\circ} \mathrm{N}, 86.845^{\circ} \mathrm{W}\right.$, summit elevation $1061 \mathrm{~m}$, Figure 1a), during the same period. Telica's summit ridge contains several craters; the active center is dominated by a $200 \mathrm{~m}$ deep, $400 \mathrm{~m}$ wide pit. Fumarolic activity is concentrated around the base of the walls and up a number of fracture zones [Roche et al., 2001]. Recent activity at Telica has been characterized by persistent degassing, punctuated by more explosive ash producing events. At the time of measurement, degassing was through fumaroles inside the crater, the floor of which was covered in rubble. There was increased activity at Telica in the months following our measurements, with some small ash and gas explosions.

\subsection{Real Time Measurements}

\subsection{1. $\mathrm{SO}_{2}, \mathrm{CO}_{2}, \mathrm{H}_{2} \mathrm{~S}$, Temperature, Humidity, and} Pressure

[10] Concentrations of $\mathrm{SO}_{2}, \mathrm{CO}_{2}$, and $\mathrm{H}_{2} \mathrm{~S}$ were monitored using a gas sensor system [Aiuppa et al., 2005b; Shinohara, 2005]. Gas was drawn into the sampler using an airchek 500 pump at $0.8 \mathrm{~L} \mathrm{~min}^{-1}$ through a $0.2 \mu \mathrm{m}$ Teflon membrane particle filter, passed through a $\mathrm{CO}_{2}$ infrared detector (Gascard II Edinburgh instruments; 0-5000 ppm) followed by a series of electrochemical sensors which detected $\mathrm{SO}_{2}(0-100 \mathrm{ppm})$ and $\mathrm{H}_{2} \mathrm{~S}(0-50 \mathrm{ppm})$. The $\mathrm{SO}_{2}$ sensor had an inbuilt filter to prevent interference from $\mathrm{H}_{2} \mathrm{~S}$. Temperature and relative humidity were measured with an external probe (Rotronics hydroclip combined $\mathrm{RH} /$ temp probe), and the whole system was housed in a weatherproof box mounted on a backpack frame. Sensors were calibrated, before and after fieldwork, with calibration gases $\left(100 \mathrm{ppm} \mathrm{SO}_{2}, 50 \mathrm{ppm} \mathrm{H}_{2} \mathrm{~S}\right.$, and $4000 \mathrm{ppm} \mathrm{CO}_{2}$ supplied to $2 \%$ accuracy) mixed with ultrapure nitrogen to provide a range of concentrations. The data logger employed with the gas sensor box offered fairly coarse resolution $\left(6.3 \mathrm{ppm} \mathrm{SO}, 20 \mathrm{ppm} \mathrm{CO}_{2}, \mathrm{H}_{2} \mathrm{~S} 3.1 \mathrm{ppm}\right.$, temperature $1{ }^{\circ} \mathrm{C}$, relative humidity $1 \%$ ) for the species studied. Despite the coarse resolution and the narrow range of gas concentrations that were encountered, we can nonetheless demonstrate the potential this technique offers for measuring gas species ratios at these volcanoes for the first time.

\subsubsection{Gaseous Elemental Mercury}

[11] Continuous mercury measurements were made using a Lumex $915+$ portable mercury vapor analyzer. The analyzer sampled filtered air at $20 \mathrm{~L} \mathrm{~min}^{-1}$. The analyzer uses differential atomic absorption spectrometry and the Zeeman Effect [Sholupov and Ganeyev, 1995]. The sampler was placed at least $1 \mathrm{~m}$ above the ground, to reduce potential interferences from resuspended dust. During sampling a zero correction was carried out to reset the baseline every $5 \mathrm{~min}$ by switching the airflow through a mercury absorption filter. We have previously described the use of the Lumex for the measurement of mercury in fumarole emissions from Vulcano, Italy, and Taiwan [Aiuppa et al., 2007; M. L. Witt et al., Fumarole compositions and mercury emissions from the Tatun Volcanic Field, Taiwan: Results from real time measurements and direct sampling techniques, submitted to Journal of Volcanology and Geothermal Research, 2008].

\subsubsection{Particle Measurements}

[12] The number of particles present in the plume was monitored with a GRIMM dust monitor (model 1.106). This is a portable optical particle monitor which allows direct mass or number concentration measurement across 14 size fractions between 0.3 and $20 \mu \mathrm{m}$ in near real-time. The GRIMM dust monitor has proved to be a very useful proxy for the volcanic plume both at Masaya and elsewhere [Allen et al., 2006; Mather et al., 2004].

\subsection{Time-Integrated Measurements \\ 2.3.1. Total Gaseous Mercury}

[13] Gold coated sand traps were employed to collect total gaseous mercury (TGM). Air was drawn through the gold trap at a rate of $0.4-0.5 \mathrm{~L} \mathrm{~min}^{-1}$ for sampling periods of 1-2 h, depending on the strength of the plume. In order 
(a)

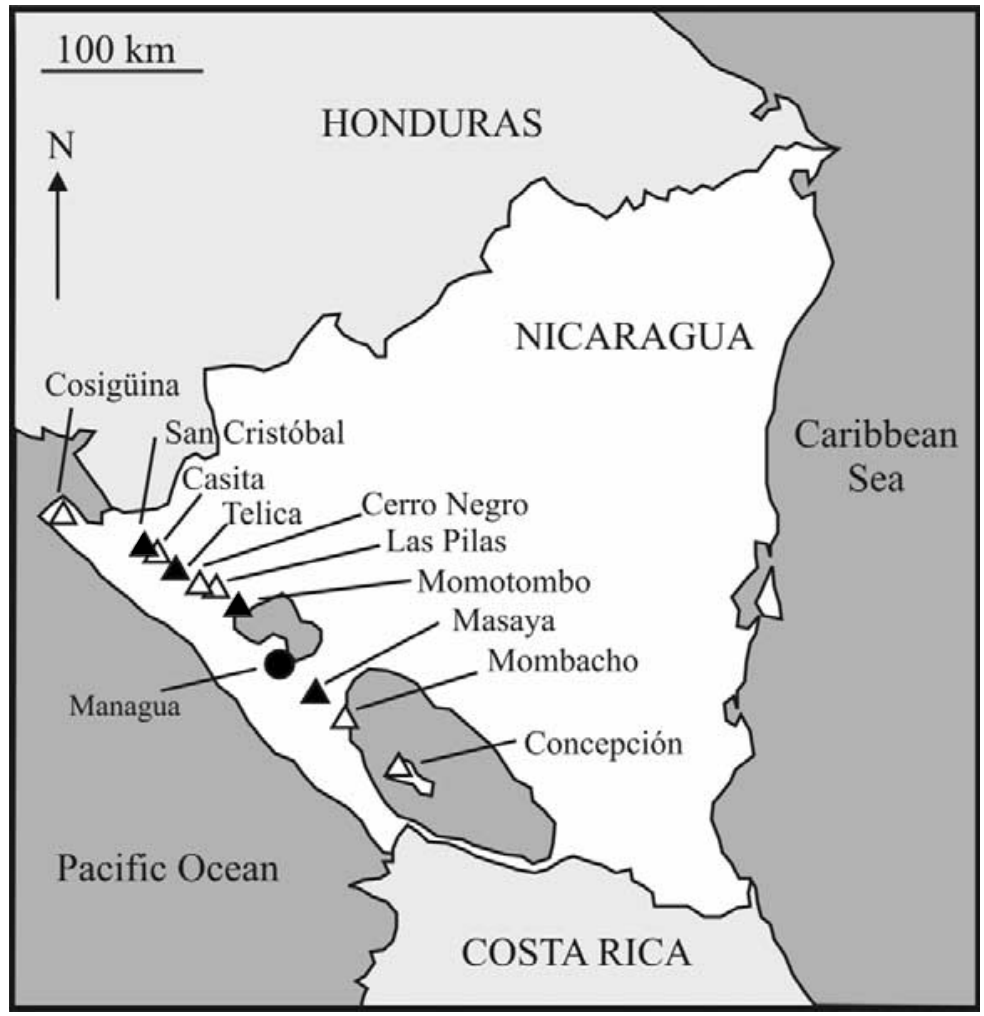

(b)

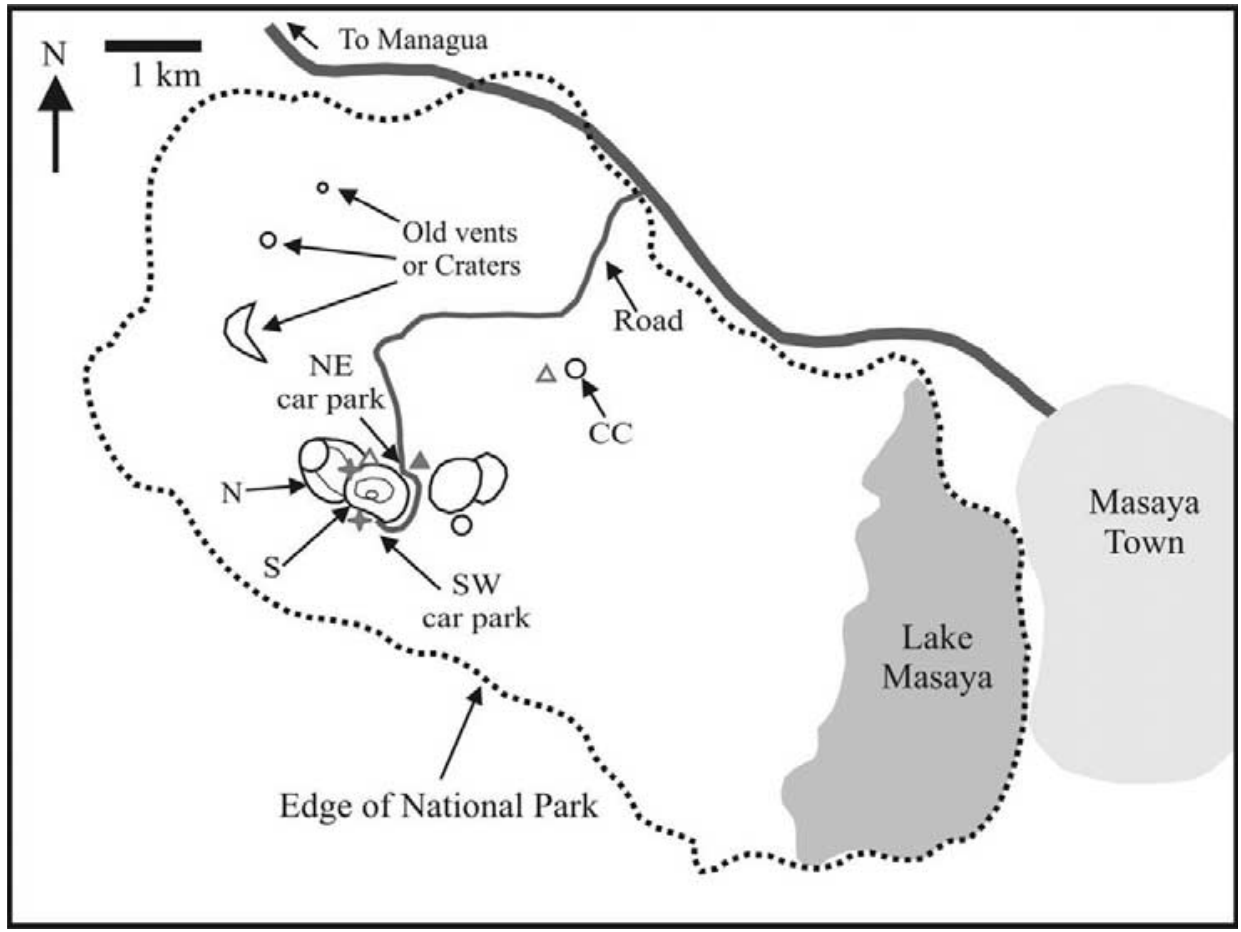

Figure 1. (a) Map showing the locations of the major volcanoes of Nicaragua. Filled triangles denote the volcanoes at which measurements were taken. (b) Map of sampling locations within Masaya National Park. N is Nindiri crater, S is Santiago crater (with the active vents), and CC is Cerro Cormalito. Crosses show locations where the main plume was sampled; open triangles show locations where fumarolic emissions were sampled. The filled triangle is the location where background measurements were made.

to measure the corresponding $\mathrm{SO}_{2}$ concentration in the gas sampled, a filter pack containing a filter impregnated with $1 \mathrm{M} \mathrm{NaHCO}_{3}$ (see section 2.2.2) was used in series with the gold traps. Following sampling, the gold traps were sealed, placed in a plastic tube, and double-bagged. The tubes were refrigerated until analysis. Gaseous mercury analysis was 
carried out at Palermo University using cold-vapor atomic fluorescence spectrometry (CVAFS, Tekran 2600). Mercury collected in the gold amalgam tube was liberated by heating the tube and transferring it to an absorption cell where it is detected by atomic absorption at $253.7 \mathrm{~nm}$. The instrument was calibrated using a series of injections of mercury gas generated by heating liquid mercury in a sealed environment [Bagnato et al., 2007]. Blank values were several orders of magnitude smaller than the values recorded in the samples. Owing to the nature of the technique and limited availability of gold traps it was not possible to collect multiple samples. However, previous studies have found good reproducibility with the gold traps [e.g., Aspmo et al., 2005; Ebinghaus et al., 1999; Schroeder et al., 1995]. On the basis of the calibration of the method, uncertainty is estimated as $25 \%$.

\subsubsection{Reactive Gaseous Mercury}

[14] Reactive gaseous mercury (RGM) was collected using an annular denuder treated with $\mathrm{KCl}$ as described by Landis et al. [2002]. The denuder had a $25.4 \mathrm{~cm}$ active annular surface length with a $1 \mathrm{~mm}$ annular space; the inner annulus tubes have a small capillary vent to release air pressure during heating. Gases were drawn through the denuder for a total of $10 \mathrm{~h}$, at a rate of $24 \mathrm{~L} \mathrm{~min}^{-1}$, over two separate occasions to accumulate sufficient material on the denuder for detection. A quartz prefilter was used to prevent particulates entering the denuder. A filter pack containing four filters, treated with $1 \mathrm{M} \mathrm{NaHCO}$ to determine the corresponding $\mathrm{SO}_{2}$ concentration (see section 2.3.4) in the gas sampled was placed after the denuder. The filter pack was changed every $1-2 \mathrm{~h}$ during sampling to avoid saturation of the $\mathrm{SO}_{2}$ filters. RGM was determined by rapidly heating the denuder to $500^{\circ} \mathrm{C}$ three times to desorb mercury species and enable detection as GEM with CVAFS. The overall mean error of this method is $\leq 15 \%$.

\subsubsection{Particulate Mercury $\left(\mathrm{Hg}_{(\mathrm{p})}\right)$}

[15] A $7 \mathrm{~mm}$ diameter quartz microfiber filter minitrap supported on a nickel grid in a glass tube in was used to measure particulate $\mathrm{Hg}$ in a number of samples. The air was drawn through the tube for $1-2 \mathrm{~h}$ at a flow rate of $\sim 3 \mathrm{~L} \mathrm{~min}^{-1}$. The exposed minitraps were stored in a sealed plastic tube with zip lock bags and kept refrigerated until analysis. To determine the particulate $\mathrm{Hg}$ content, the traps were pyrolysed (heated to $800-900^{\circ} \mathrm{C}$ in a stream of argon) to decompose all of the mercury present to elemental $\mathrm{Hg}$ gas. This enabled the transfer of gaseous $\mathrm{Hg}$ to a gold amalgam trap where it can be analyzed with the Tekran instrument as described for the GEM analysis. The precision of this method is hindered by the presence of $\mathrm{SO}_{2}$ and uncertainty is estimated as $\pm 30 \%$ [Bagnato et al., 2007].

\subsubsection{Ratios of $\mathrm{SO}_{2}, \mathrm{HCl}, \mathrm{HBr}$, and $\mathrm{HI}$}

[16] Measurements were made at the crater rim at Masaya between 24 February and 6 March 2006 and at the crater rim of Telica volcano on 27 February 2006. Background measurements were made upwind of the active crater within the Masaya national park (Figure 1b).

[17] Air was pumped at a known flow rate (from $\sim 12$ to $28 \mathrm{~L} \mathrm{~min}^{-1}$ ) through filter packs containing four filters in series for 70-117 min. The first filter collected solid and liquid particles and the subsequent three filters were impregnated with $1 \mathrm{M} \mathrm{NaHCO}$ to trap acidic gaseous volatiles. $\mathrm{SO}_{2}, \mathrm{HCl}, \mathrm{HBr}$, and $\mathrm{HI}$ collected on the filters was measured according to the methodology detailed by Aiuppa et al. [2005a] with ICP-MS used for $\mathrm{Cl}, \mathrm{Br}$ and I and HPLC used for S. On the basis of triplicate analyses of samples the uncertainties in the ICP-MS measurements for $\mathrm{Cl}, \mathrm{Br}$ and I are $\pm 10 \%, \pm 11 \%$, and $\pm 19 \%$, respectively. Errors in the determination of S by HPLC are estimated as approximately $\pm 10 \%$. Blank filters and field blanks (i.e., filters from filter packs transported into the field and back in an identical manner to samples but not attached to a pump) were also analyzed.

\subsubsection{Fluxes of $\mathrm{SO}_{2}$}

[18] Sulfur dioxide flux measurements were made using a UV spectrometer at Masaya on 22 and 25 February and 2 and 4 March and at Telica, San Cristóbal, and Momotombo on 27 February and 5 March. The methodology used, and a detailed error analysis, is presented elsewhere [Mather et $a l ., 2006]$. Wind speeds were determined from HYSPLIT model trajectories [Draxler and Rolph, 2003].

\section{Results and Discussion}

\subsection{Sulfur Dioxide Fluxes}

[19] The results from the traverses at Masaya volcano are presented in Table 1. Considerable variation can be seen between the measurements made on 22 and 25 February and those made on 4 March. This variability is greater than that observed between days in November and December 2003 [Mather et al., 2006] but is consistent with other measurements made during the same time period in 2006 [Nadeau and Williams-Jones, 2008]. All the flux measurements presented here $\left(650-1700 \mathrm{Mg} \mathrm{d}^{-1}\right)$ suggest that the $\mathrm{SO}_{2}$ flux from Masaya is larger than it was during the 2003 measurement period (mean of $220 \mathrm{Mg} \mathrm{d}^{-1}$ ). Despite attempting measurements on two different days at Telica, San Cristóbal, and Momotombo, it was not possible to resolve the $\mathrm{SO}_{2}$ plumes, and $\mathrm{SO}_{2}$ fluxes could not be retrieved. Similar difficulties were experienced previously at Momotombo, which were attributed to the dilute nature of its plume [Mather et al., 2006]; the difficulties experienced at Telica and San Cristóbal may have been due to a combination of high wind speeds and plume-grounding.

\subsection{Concentrations of $\mathrm{SO}_{2}$ and Halogen Species Near the Active Vents at Masaya and Telica}

[20] The mean concentrations of $\mathrm{SO}_{2}, \mathrm{HCl}, \mathrm{HBr}$, and $\mathrm{HI}$ are presented in Table 2. Concentrations of gaseous plume species at crater rims depend on both volcanic (gas flux) and nonvolcanic factors (extent of mixing and dilution in the vent, wind speed, and direction), hence comparing the concentrations of species between different volcanoes is not necessarily meaningful. That said, the $\mathrm{SO}_{2}$ and $\mathrm{HCl}$ concentrations that we report in Table 2 are in line with other recent measurements at Masaya [Mather et al., 2006]. Background levels were similar to those from previous studies for $\mathrm{SO}_{2}$ and $\mathrm{HCl}\left(\sim 0.01 \mathrm{mg} \mathrm{m}^{-3}\right.$ [Mather et al., 2006]) and below the detection limit for $\mathrm{HBr}$ and HI. Filter blanks were not significant for any species and field blanks were only significant when compared to the $\mathrm{SO}_{2}$ and $\mathrm{HCl}$ background levels.

\subsection{Ratios of $\mathbf{S}$ and Halogen Species}

[21] Mean molar $\mathrm{HBr} / \mathrm{SO}_{2}$ ratios were $3.0 \times 10^{-4}$ for both Masaya and Telica, with $\mathrm{HI} / \mathrm{SO}_{2}$ being $2.0 \times 10^{-5}$ and 
Table 1. Sulphur Dioxide Fluxes Measured at Masaya

\begin{tabular}{cccc}
\hline Date in 2006 & Time (UT) & $\begin{array}{c}\text { Wind Speed } \\
\left(\mathrm{m} \mathrm{s}^{-1}\right)\end{array}$ & $\begin{array}{c}\mathrm{SO}_{2} \text { Flux } \\
\left(\mathrm{Mg} \mathrm{d}^{-1}\right)^{\mathrm{a}}\end{array}$ \\
\hline 22 Feb & $2220-2225$ & 11.4 & 1845 \\
& $2242-2245$ & 11.5 & 1564 \\
& & & $\begin{array}{c}\text { Day mean: } \\
1700 \pm 200\end{array}$ \\
25 Feb & $2141-2145$ & 14.2 & 1669 \\
& $2157-2200$ & 14.8 & 1218 \\
& $2207-2213$ & 14.8 & 1163 \\
& $2218-2223$ & 15.4 & 1463 \\
& $2231-2234$ & 15.4 & 1315 \\
& $2241-2246$ & 16.0 & 2191 \\
& & & Day mean: \\
2 Mar & $2136-2141$ & & $1500 \pm 380$ \\
& $2106-2109$ & 11.2 & 1040 \\
& $2116-2118$ & 11.8 & 408 \\
& $2124-2127$ & 11.8 & 614 \\
& $2135-2138$ & 11.8 & 349 \\
& $2141-2145$ & 12.5 & 843 \\
& & & Day mean: \\
& & & $650 \pm 290$ \\
\hline
\end{tabular}

${ }^{a}$ Errors are based on 1 standard deviation.

$5.8 \times 10^{-5}$ for Masaya and Telica, respectively (Table 2). Combined with the $\mathrm{SO}_{2}$ flux measurements discussed in section 3.1 and Table 1 , this equates to $\mathrm{HBr}$ fluxes of $0.2-$ $0.5 \mathrm{Mg} \mathrm{d}^{-1}\left(0.07-0.18 \mathrm{kt} \mathrm{a}^{-1}\right)$ and $0.2 \mathrm{Mg} \mathrm{d}^{-1}\left(0.07 \mathrm{kt} \mathrm{a}^{-1}\right)$ for Masaya and Telica, respectively, and HI fluxes of $0.02-0.05 \mathrm{Mg} \mathrm{d}^{-1}\left(0.007-0.018 \mathrm{kt} \mathrm{a}^{-1}\right)$ and $0.06 \mathrm{Mg} \mathrm{d}^{-1}$ $\left(0.02 \mathrm{kt} \mathrm{a}^{-1}\right)$ for Masaya and Telica, respectively (Table 2).

[22] Molar $\mathrm{HBr} / \mathrm{SO}_{2}$ ratios are similar to those measured by Aiuppa et al. [2005a] in the high-temperature emissions from Mount Etna volcano, Italy, $\left(3.2-7.4 \times 10^{-4}\right)$ reinforcing their estimate of the global volcanic $\mathrm{HBr}$ flux based on these ratios. However, our $\mathrm{HI} / \mathrm{SO}_{2}$ molar ratios are higher than those measured from Etna $\left(4.0-6.7 \times 10^{-6}\right)$. Using our $\mathrm{HI} / \mathrm{SO}_{2}$ ratios (Table 2) and a global $\mathrm{SO}_{2}$ flux of $14000 \pm$ $6000 \mathrm{kt} \mathrm{a}^{-1}$ [Aiuppa et al., 2005a] yields a global HI flux of $0.2-2.3 \mathrm{kt} \mathrm{a}^{-1}$, consistent with the estimate of $0.2-7.7 \mathrm{kt} \mathrm{a}^{-1}$ made by Snyder and Fehn [2002] based on thermal waters and reservoir brines in Central America. Aiuppa et al. [2005a] found considerable variation in halogen to sulphur ratios at Etna with volcanic activity and so some of the differences between different volcanoes might be symptomatic of different stages of magma degassing and evolution.

[23] In contrast, Aiuppa et al. [2005a] found the halogen to halogen ratios at Etna to be stable over time. We find mean molar ratios of $1190 \pm 310(\mathrm{Cl} / \mathrm{Br})$ and $18200 \pm 4300(\mathrm{Cl} / \mathrm{I})$ for Masaya and $1660 \pm 430(\mathrm{Cl} / \mathrm{Br})$ and $7747 \pm 47(\mathrm{Cl} / \mathrm{I})$ for Telica (Figure 2). These $\mathrm{Cl} / \mathrm{Br}$ values are in broad agreement with the ratios measured in Masaya aerosol in 1981 ( 930 \pm 300 [Stoiber et al., 1986]); in Telica condensates in 1981 (2160 [Gemmell, 1987]), and with those from Etna [Aiuppa et al., 2005a]. Measured $\mathrm{Cl} / \mathrm{Br}$ ratios are only a little higher than mean seawater and continental crust (Figure 2). Our new measurements of $\mathrm{Cl} / \mathrm{Br}$ in high-temperature emissions from arc volcanoes (rather than the fumarolic condensate data compiled by Gerlach [2004]) do not support the suggestion that $\mathrm{Cl} / \mathrm{Br}$ ratios of arc volcano gases are lower than rift or hot spot volcanoes [Aiuppa et al., 2005a].

[24] $\mathrm{The} \mathrm{Cl} / \mathrm{I}$ ratios from Nicaragua are considerably lower than those from Etna [Aiuppa et al., 2005a, Figure 2], as are the $\mathrm{S} / \mathrm{I}$ ratios discussed above. In fact, the Masaya and Telica volcanic gas compositions are markedly more enriched in I, relative to $\mathrm{Br}$ and $\mathrm{Cl}$, than both the gases from Etna and hot springs from the Cascades [Hurwitz et al., 2005]. Given the few constraints on halogen melt-vapor partition coefficients (the only data being from water-saturated, iron-free silicic melts relevant to naturally occurring magmas of rhyolitic composition [Bureau et al., 2000; Bureau and Metrich, 2003]), it remains possible that this signature reflects differences between the degassing melts or the degassing process. We consider it more likely, though, that the extent of I enrichment in the volatile phase reflects the contributions from a deeper source. Here, again, there are few constraints. The subduction budget of the halogens is expected to be dominated by the sediment contribution, and in particular the contribution from pore waters [Jarrard, 2003]. The iodine budget will also be very sensitive to the amount of organic $\mathrm{C}$ being subducted, while the I flux into the subarc mantle will depend on the extent to which the organic carbon is oxidized, and iodine is lost into dewatering fluids, at shallow levels in the trench [e.g., Martin et al., 1993]. Qualitatively, the more

Table 2. Mean Measured Concentrations of Gaseous $\mathrm{SO}_{2}, \mathrm{HCl}, \mathrm{HBr}$, and $\mathrm{HI}$ at the Crater Rim, Ratios $H X / \mathrm{SO}_{2}$ $(H X=$ Halogen Halide), and Halogen Fluxes in the Plumes of Masaya and Telica

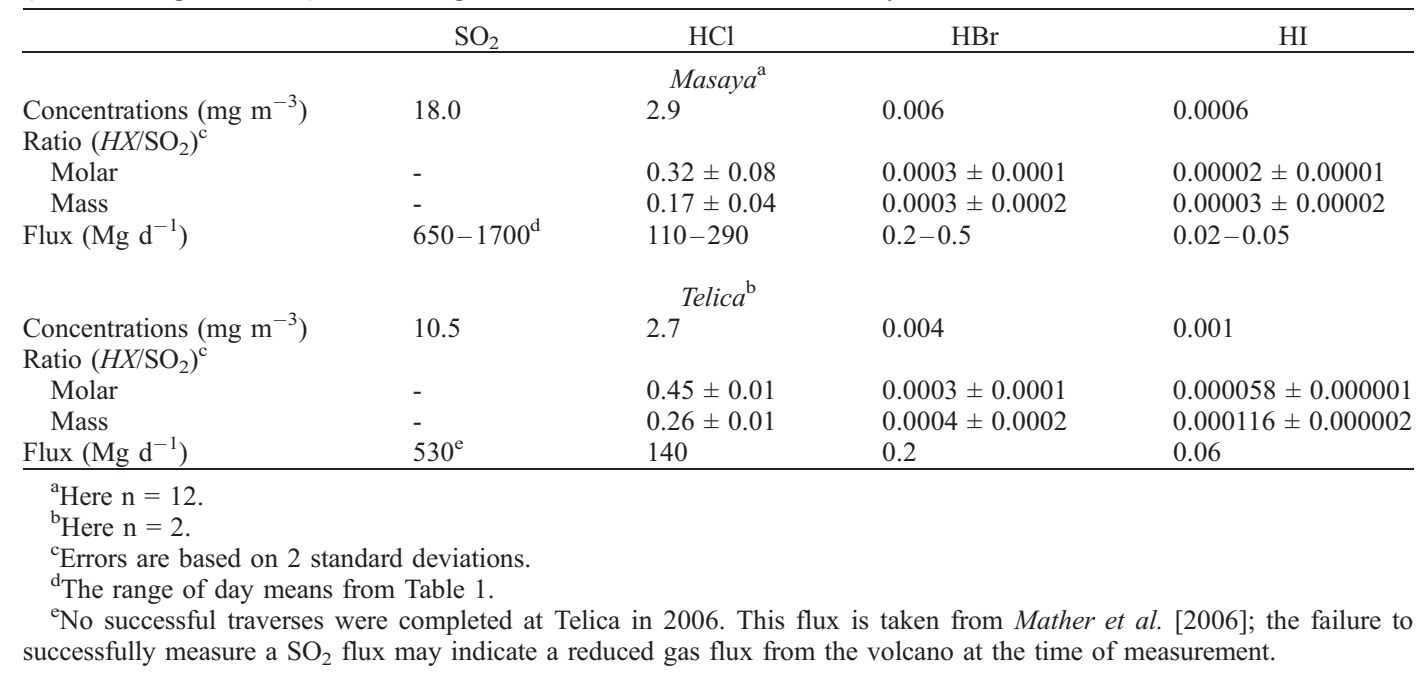




\section{$\mathrm{Cl} / 1000$}

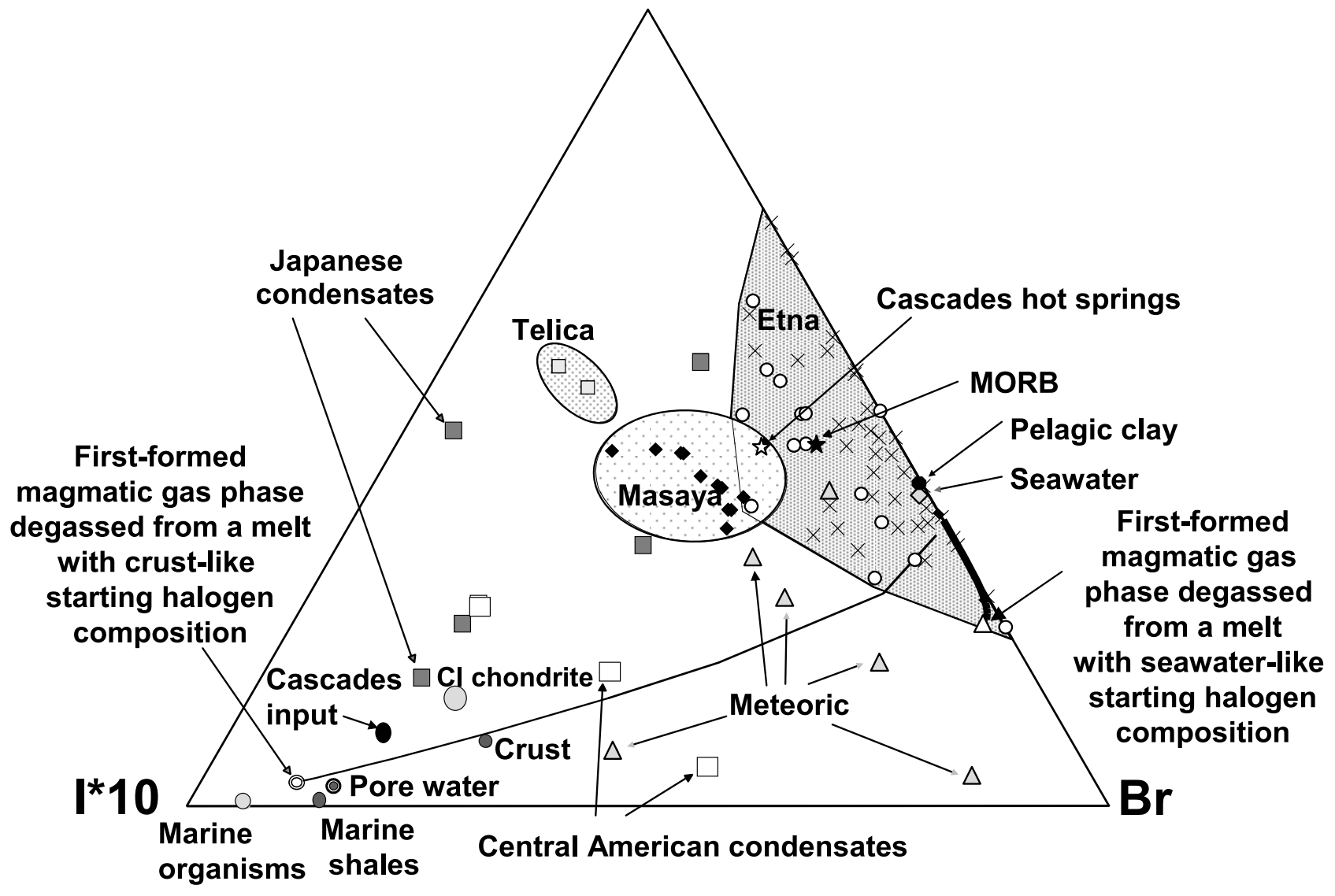

Figure 2. Triangular plot showing the molar covariance of $\mathrm{Cl}, \mathrm{Br}$, and $\mathrm{I}$ in the volcanic gases from Masaya (closed diamonds), Telica (open squares), and the Northeast (crosses) and Voragine (open circles) craters of Mount Etna, Italy [Aiuppa et al., 2005a]. Compositions are also shown for mean ocean water $(\mathrm{Cl} / \mathrm{Br}=651$ and $\mathrm{Cl} / \mathrm{I}=1190000 ;$ [Nozaki, 1997]), meteoric water measured in rivers and lakes in Central America [Snyder and Fehn, 2002], Central American fumarolic condensates $\left(153-281^{\circ} \mathrm{C}\right.$, [Snyder and Fehn, 2002]); Japanese fumarolic condensates [Honda, 1970]; continental crust [Newsom, 1995], MORB [Johnson et al., 2000], CI chondrite [Johnson et al., 2000], pore water samples [Egeberg and Dickens, 1999], and typical marine organisms, marine shales and pelagic sediments, and the input and output to the Cascadia arc [Hurwitz et al., 2005]. We also plot the trends for gas compositions produced by open system Rayleigh degassing of magma with crustal or seawater halogen starting compositions, based on the partition coefficients presented by Bureau et al. [2000] and modeling the system as Rayleigh type open system degassing.

I-rich compositions of subduction-related fluids, gases, and condensates from Central America and the Cascades compared to Etna, are consistent with a subduction source for I; in accord with studies of ${ }^{129} \mathrm{I}$ in subduction-zone products [Snyder and Fehn, 2002]. Differences between halogen outputs from the Cascadia arc and the Central American arc are most likely to reflect the subduction of a different sedimentary stratigraphy at the two trenches (clastic sediments versus siliceous oozes and carbonates, respectively [Plank and Langmuir, 1998]).

[25] In general, the volcanic samples are more enriched in $\mathrm{Cl}$ than many other terrestrial reservoirs (Figure 2). A similar pattern of halogen fractionation is observed at Etna and in Nicaragua (if we take crust or marine pore water compositions as a starting point) as in the Cascadia arc. If the melt-vapor partition coefficients of Bureau et al.
[2000] are even qualitatively correct our degassing curves suggest that the levels of I are too high in the volcanic vapors for degassing to account for the $\mathrm{Cl}$ enrichment. In the absence of a plausible Cl-rich end-member we can only speculate that some sort of fractionation process is occurring that favors $\mathrm{Cl}$ concentration into the melts or associated fluids phase at some stage during magmagenesis and transport to the surface. This highlights the need for more experimental data on the fluid-melt partitioning behavior of halogens in magmas of different compositions as well as further gas measurements and petrological studies of volcanic samples to understand their behavior in natural systems.

\subsection{MultiGas Sensor Results}

[26] $\mathrm{CO}_{2}$ and $\mathrm{SO}_{2}$ were monitored continuously at Masaya with the IR and electrochemical sensors. Previous 

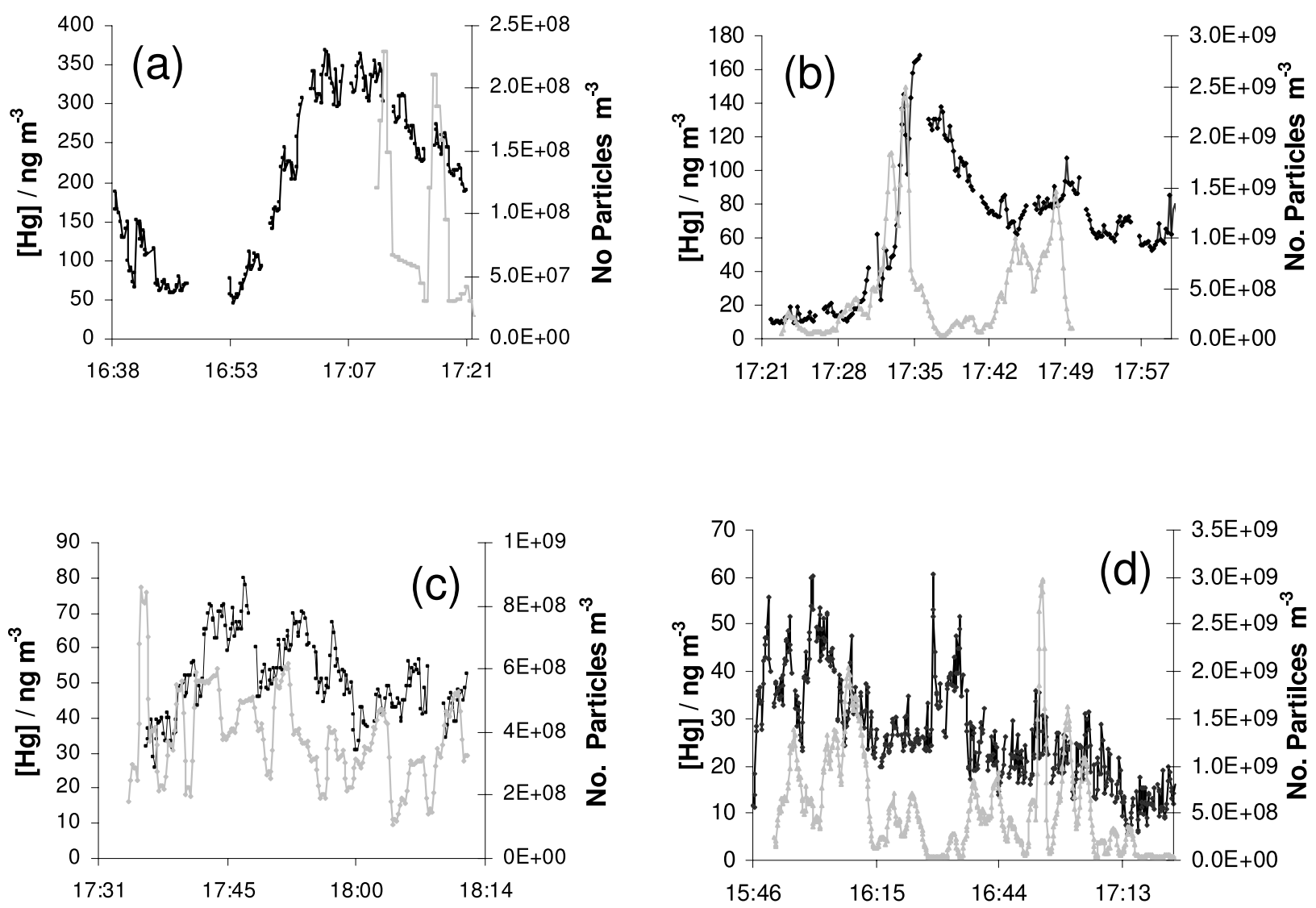

Figure 3. Mercury concentration (black) and number of particles (gray) recorded at Masaya, February 2006, time shown UTC. Data recorded (a) 23 February Sapper, (b) 24 February Sapper, (c) 25 February Nindiri, (d) 26 February Sapper.

studies of the composition of Masaya's plume found a $\mathrm{CO}_{2}: \mathrm{SO}_{2}$ molar ratio of $1.5-2.9$ and $\mathrm{H}_{2} \mathrm{O}: \mathrm{SO}_{2}$ ratios of 66-69 [Burton et al., 2000]. Despite the coarse data resolution, the $\mathrm{CO}_{2}: \mathrm{SO}_{2}$ molar ratio recorded with the gas sensor box (based on 1 min averages) at Masaya $(3.5 \pm 0.4)$ are reasonably consistent with these previous measurements. As observed in previous studies [Duffell et al., 2003; Stoiber et al., 1986], little or no $\mathrm{H}_{2} \mathrm{~S}$ was detected in the gases at Masaya.

\subsection{Measurements of GEM in the Volcanic Plume With the Lumex Instrument}

[27] The background concentration of mercury was measured a number of times during the field campaign with the Lumex at a site on Masaya upwind from the volcanic gases (Figure 1b). A background of $20 \mathrm{ng} \mathrm{m}^{-3}$ was recorded at the start of the Masaya study (22 February), the background values measured with the Lumex over the campaign dropped steadily to $6.1 \mathrm{ng} \mathrm{m}^{-3}$ by 2 March. This decrease in background GEM values was possibly a result of contamination of the instrument's zero $\mathrm{Hg}$ filter leading to a raised baseline. Limited availability of gold traps meant we were unable to record a background TGM concentration with these.

[28] The Lumex analyzer detected GEM in Masaya's plume on each day that sampling was carried out. Figure 3 shows the changes in GEM concentration as 10 or $6 \mathrm{~s}$ averages along with the number of particles (data from the GRIMM) measured near the vent for the first few days of the field campaign. During sampling it was noted that GEM peaks were often detected later than corresponding peaks in particles number. The offset in the particle and GEM peaks may be due to differences in the pump rates or the small distance between sample inlets or differences in the transport dynamics between gases and particles. Exposure to the volcanic gases was not continuous at the sampling locations. At times the plume was lofted above the instruments or blown in the opposite direction. These gusts of plume are reflected in the variability in signal shown in Figure 3. When sampling the volcanic gases, the GEM concentrations were consistently above the background levels.

\subsection{Time-Integrated Mercury Results}

\subsubsection{Total Gaseous Mercury}

[29] Mercury concentrations recorded using gold trap methods are reported in Table 3. Between 100 and $225 \mathrm{ng}$ TGM $\mathrm{m}^{-3}$ were recorded at Masaya in the main plume gases. The lowest TGM was observed on 4 March, close to the time a decreased $\mathrm{SO}_{2}$ flux was also observed. On all occasions that measurements were made, TGM concentrations were approximately an order of magnitude 
Table 3. $\mathrm{Hg}$ and $\mathrm{SO}_{2}$ Concentrations and Ratios at Masaya Determined by Direct Sampling ${ }^{\mathrm{a}}$

\begin{tabular}{|c|c|c|c|c|c|c|c|c|}
\hline Location and Date & $\begin{array}{l}\mathrm{TGM} \\
\mathrm{ng} / \mathrm{m}^{3}\end{array}$ & $\begin{array}{l}\mathrm{Hg}(\mathrm{p}) \\
\mathrm{ng} / \mathrm{m}^{3}\end{array}$ & $\begin{array}{c}\mathrm{SO}_{2} \\
\mu \mathrm{g} / \mathrm{m}^{3}\end{array}$ & $\begin{array}{c}\mathrm{TGM} / \mathrm{SO}_{2} \\
\text { (mass) }\end{array}$ & $\mathrm{Hg}(\mathrm{p}) / \mathrm{SO}_{2}$ (mass) & $\underset{\mathrm{Mg} \mathrm{d}^{-1}}{\mathrm{SO}_{2} \text { Flux }}$ & $\begin{array}{l}\text { TGM Flux } \\
\mathrm{Mg} \mathrm{a}^{-1}\end{array}$ & $\begin{array}{c}\mathrm{Hg}_{\text {(tot) }} \text { Flux } \\
\mathrm{Mg} \mathrm{a}^{-1}\end{array}$ \\
\hline Nindiri 24/02/06 & 225.0 & 3.8 & 20600 & $1.09 \times 10^{-5}$ & $0.19 \times 10^{-7}$ & 1700 & 6.78 & 6.89 \\
\hline Sapper 26/02/06 & 140.2 & 10.3 & 8100 & $1.74 \times 10^{-5}$ & $1.28 \times 10^{-6}$ & 1500 & 9.52 & 10.23 \\
\hline Sapper 01/03/06 & 157.7 & 13.7 & 9600 & $1.64 \times 10^{-5}$ & $1.43 \times 10^{-6}$ & 1130 & 6.78 & 7.37 \\
\hline Nindiri $03 / 03 / 06$ & 193.1 & n.d. & 5200 & $3.74 \times 10^{-5}$ & n.d. & 650 & 8.87 & \\
\hline Sapper $04 / 03 / 06$ & 101.7 & 4.2 & 5700 & $1.79 \times 10^{-5}$ & $0.74 \times 10^{-6}$ & 650 & 4.26 & 4.43 \\
\hline Average \pm 1 s.d. & $163.5 \pm 48$ & $8.0 \pm 4.8$ & 11000 & $2.00 \times 10^{-5} \pm 1 \times 10^{-5}$ & $0.91 \times 10^{-6} \pm 0.6 \times 10^{-6}$ & & $7.24 \pm 2.1$ & $7.23 \pm 2.4$ \\
\hline
\end{tabular}

${ }^{\mathrm{a}} \mathrm{TGM}$ data are from gold traps, $\mathrm{Hg}(\mathrm{p})$ data from minitraps. Here n.d. is not determined.

higher than background concentrations measured with the Lumex instrument. Variations in the concentrations of TGM measured are to be expected as the dilution of the plume changes with weather conditions at the sampling location.

\subsubsection{Particulate Mercury and Reactive Gaseous}

Mercury

[30] Particulate $\mathrm{Hg}$ concentrations between 3.8 and $13.7 \mathrm{ng} \mathrm{m}^{-3}$ were recorded in Masaya's plume (Table 3), comprising between 1.7 and $8.0 \%$ of the total $\mathrm{Hg}$ present (Table 4). This is high, when compared to the few other volcanoes for which reliable modern data exist, such as Etna $(1-2 \%)$, La Soufrière, Guadelupe $(1-2 \%)$, and Miyake Jima (0.4-0.7\%) [Bagnato, 2007; Bagnato et al., 2007]. Varekamp and Buseck [1986] proposed that particulate $\mathrm{Hg}$ in volcanic plumes is enhanced by the presence of $\mathrm{H}_{2} \mathrm{SO}_{4}$ in which $\mathrm{Hg}$ is soluble. Significant fluxes of $\mathrm{H}_{2} \mathrm{SO}_{4}$ have been detected from Masaya and this may have contributed to the enhanced $\mathrm{Hg}_{(\mathrm{p})}$ formation [Mather et al., 2006]. The concentrations of $\mathrm{Hg}_{(\mathrm{p})}$ observed at Masaya were well above general background concentrations of around $25 \mathrm{pg} \mathrm{m}^{-3}$ [Poissant et al., 2005; Valente et al., 2007], and exceed typical urban concentrations (e.g., 6-60 $\mathrm{pg} \mathrm{m}^{-3}$ in industrial Detroit [Lynam and Keeler, 2006]).

[31] The mean RGM content at Masaya, measured using a single denuder over two separate sampling periods on 1 and 6 March, was $2 \mathrm{ng} \mathrm{RGM} \mathrm{m}{ }^{-3}$, or $1.2 \%$ of the average total $\mathrm{Hg}$ detected (Table 4). In Etna's plume, measured RGM concentrations are higher $\left(6 \mathrm{ng} \mathrm{m}^{-3}\right)$, but account for a similar proportion of TGM [Bagnato et al., 2007]. At clean air sites elsewhere, RGM typically comprises $\sim 0.3 \%$ (concentrations of $5-50 \mathrm{pg} \mathrm{m}^{-3}$ ) of TGM [Poissant et al., 2005; Valente et al., 2007]. These are the first sets of modern RGM measurements on volcanoes, and they are sufficient to demonstrate the importance of volcanoes as a source of RGM. However, from these sparse data alone, it is not possible to determine the origin of the RGM (for example, whether it is emitted directly from magma or produced by reaction in the plume) or the potential roles of plume chemistry $\left(\mathrm{HCl}, \mathrm{SO}_{2}, \mathrm{HBr}\right)$, local meteorology and air mass composition $\left(\mathrm{T}, \mathrm{RH}, \mathrm{O}_{3}\right)$, and photochemistry on volcanic $\mathrm{Hg}$ speciation [cf. Ghorishi et al., 2005; Lindberg and Stratton, 1998; Lynam and Keeler, 2006]. Much further work is needed in this regard.

[32] The $\mathrm{Hg}_{(\mathrm{p})}$ and RGM fluxes from Masaya are estimated as 414 and $82 \mathrm{~kg} \mathrm{a}^{-1}$, respectively (Table 4). This is a small fraction of the TGM flux, but as these reactive species are more readily removed from the atmosphere than GEM, they are likely to be important in terms of the environmental impact of degassing volcanoes on the immediate areas downwind.

\subsection{Comparison of Lumex and Gold Trap Mercury Techniques at Masaya}

[33] Previous comparisons of gold traps and Lumex $\mathrm{Hg}$ detection techniques by Kim et al. [2006] found the gold trap method detected about 1.2 times the amount detected by the Lumex instrument. At Masaya, $\mathrm{Hg}$ detected with gold trap techniques was 5 to 19 times higher than those recorded simultaneously by the Lumex. This contrasts with our experience at Vulcano, with a different Lumex instrument, where the agreement was much better [Aiuppa et al., 2007]. We consider it unlikely that the difference is real; a more likely possibility is that contamination of the blank filter in the Lumex led to a rise in the baseline measurement of the instrument, as suggested by the lowering of background GEM readings. High levels of acid gases and high humidity may also have hindered the spectrophometric detection of GEM, and in future analyses with the instrument pretreatment of the gas with a desiccant and the introduction of an alkali-impregnated filter may help in avoiding these difficulties although this could lead to loss of $\mathrm{Hg}$ to these surfaces and affect the flow rate of the Lumex. The comparison of the $\mathrm{Hg}$ techniques by Kim et al. [2006] was carried out in ambient air and concentrations of GEM were generally far lower than those found at Masaya. While confidence in the absolute values of the Lumex instrument may be limited, we were able to detect changes in the GEM at the sampling site due to wind-derived changes in the dilution of volcanic gases with background air with greater certainty.

\section{8. $\mathrm{Hg} / \mathrm{CO}_{2}$ and $\mathrm{Hg} / \mathrm{SO}_{2}$ Ratios}

[34] The GEM data from the real-time measurements at Masaya does not generally correlate well with the realtime measurements of $\mathrm{SO}_{2}$ or $\mathrm{CO}_{2}$ at the vent. This is in part because of the lack of resolution in the $\mathrm{SO}_{2}$ and $\mathrm{CO}_{2}$ data, which makes it difficult to see the changes in these components. By averaging $\mathrm{CO}_{2}$ and GEM concentrations over 1 min periods, we determined that the average $\mathrm{GEM} / \mathrm{CO}_{2}$ mass ratio in Masaya's plume was of the order

Table 4. Mercury Speciation at Masaya

\begin{tabular}{|c|c|c|c|c|}
\hline & TGM & GEM & $\mathrm{Hg}_{(\mathrm{p})}$ & RGM \\
\hline $\begin{array}{l}\text { Concentration } \\
\qquad\left(\mathrm{ng} \mathrm{m}^{-3}\right)\end{array}$ & 163 & 161 & 8 & 2 \\
\hline $\begin{array}{l}\text { Percentage of } \\
\text { total } \mathrm{Hg}\end{array}$ & & $94.2 \%$ & $4.7 \%$ & $1.2 \%$ \\
\hline $\begin{array}{l}\mathrm{Hg} / \mathrm{SO}_{2} \\
\quad \text { (mass) }\end{array}$ & $20.0 \times 10^{-6}$ & $19.8 \times 10^{-6}$ & $0.91 \times 10^{-6}$ & $0.18 \times 10^{-6}$ \\
\hline $\begin{array}{l}\mathrm{Hg} \text { Flux } \\
\left.\qquad \mathrm{kg} \mathrm{a}^{-1}\right)\end{array}$ & 7240 & 7160 & 414 & 82 \\
\hline
\end{tabular}




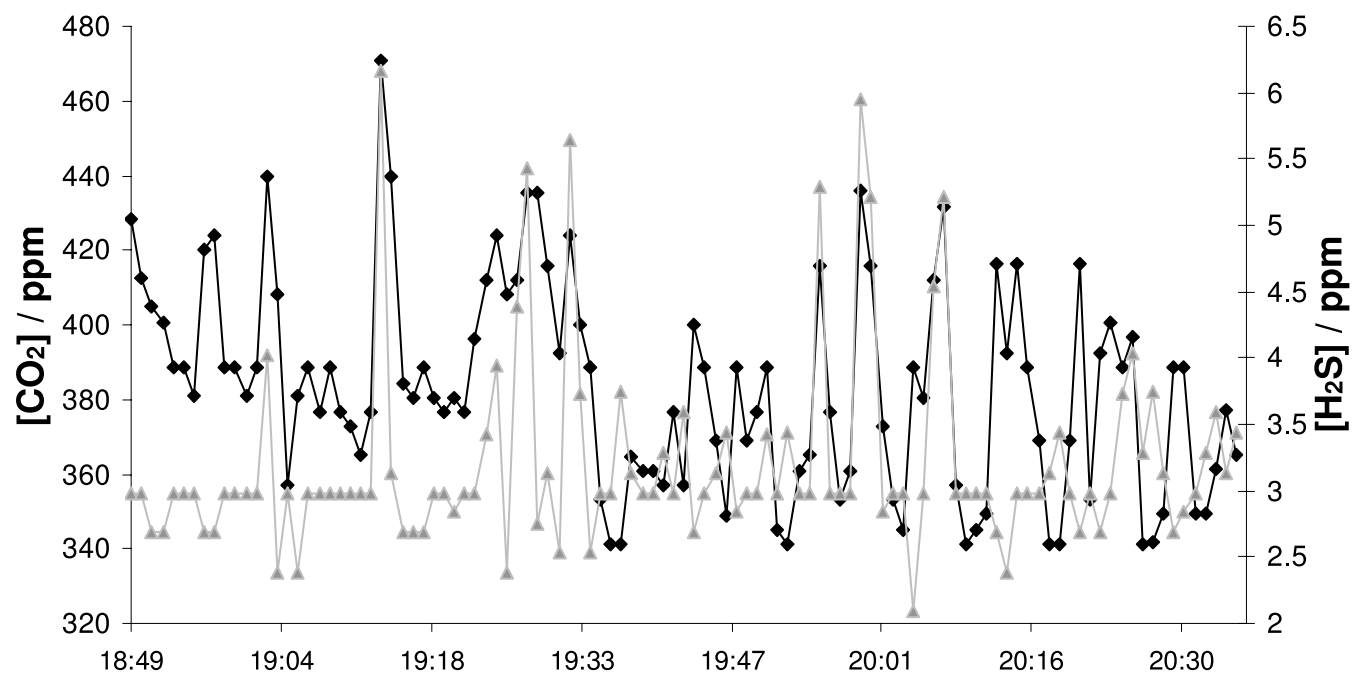

Figure 4. $\mathrm{CO}_{2}$ (black) and $\mathrm{H}_{2} \mathrm{~S}$ (light gray) concentrations recorded at Telica, 27 February 2006. $\mathrm{H}_{2} \mathrm{~S}$ concentration corrected for $\mathrm{SO}_{2}$ cross-sensitivity determined during calibration.

of $10^{-7}$. The $\mathrm{TGM} / \mathrm{SO}_{2}$ ratio was determined at Masaya on a number of occasions using gold traps and filter packs. These results are reported in Table 3 with the TGM flux calculated from the $\mathrm{SO}_{2}$ flux determined from DOAS measurements at a similar time (see section 3.1). The mass ratios recorded at Masaya by time integrated sampling varied between 1.1 and $3.7 \times 10^{-5}$. The highest $\mathrm{TGM} / \mathrm{SO}_{2}$ ratios were observed on 3 and 4 March, which was also when the $\mathrm{SO}_{2}$ flux dropped below that seen earlier in the campaign. The ratios measured at the two locations on Masaya were similar and are consistent with a common source for the gas encountered. These are the first measurements of this kind of the $\mathrm{Hg} / \mathrm{SO}_{2}$ ratio at Masaya, but they are within the range of $\mathrm{Hg} / \mathrm{SO}_{2}$ ratios previously observed at other volcanoes [Pyle and Mather, 2003].

[35] These are some of the first measurements of mercury from volcanoes made with the CVAFS technique. The ratio observed at Masaya, however, is around an order of magnitude higher than was observed at Mount Etna and Vulcano with similar techniques. Measurements with the same gold and filter traps at Mount Etna found a lower $\mathrm{Hg} / \mathrm{SO}_{2}$ ratio of $8.7 \times 10^{-6}$ [Bagnato et al., 2007]. Measurements made with a variety of techniques at a fumarole of La Fossa Crater, Vulcano, also recorded lower $\mathrm{Hg} / \mathrm{SO}_{2}$ ratios between 0.96 and $2.6 \times 10^{-6}$ [Aiuppa et al., 2007].

[36] The most likely reason for this difference may simply be the composition (i.e., $\mathrm{Hg}$ and $\mathrm{S}$ contents) of the degassing magma: Etna's alkaline basaltic magmas are very S-rich, with a substantial supply of volatiles from deep, degassing melt [e.g., Caltabiano et al., 2004]. At Masaya, the tholeiitic basalts are strongly degassed and S-poor [e.g., Mather et al., 2006; Stoiber et al., 1986]. While there are no systematic data which allow us properly to test this hypothesis, it is consistent with available literature data: the typical $\mathrm{Hg} / \mathrm{SO}_{2}$ mass ratio for Etna lavas (based on a compiled "average" composition with $40 \mathrm{ppb} \mathrm{Hg}$ and $2800 \mathrm{ppm} \mathrm{S}$; Aiuppa et al. [2003]) is $\sim 7 \times 10^{-6}$, while that for Masaya is $\sim 30 \times$ $10^{-6}$, based on a typical bulk lava composition of $\sim 21 \mathrm{ppb}$ $\mathrm{Hg}$ [Crenshaw et al., 1982] and 320 ppm S [Stoiber et al., 1986]. The different temperatures of degassing at various volcanic systems could also play a role due to the influence of temperature on the chemistry of near source volcanic emissions [Bagnato et al., 2007; Martin et al., 2006]. More work is required to establish the factors which control the metal:sulfur ratios at different degassing volcanoes.

\subsection{Fumarole Gases}

[37] At Telica's summit, the gases encountered were largely from fumaroles. $\mathrm{Hg}$ measurements were not made at this location. The gas sensor detected very little $\mathrm{SO}_{2}$ but some $\mathrm{H}_{2} \mathrm{~S}$ (3-6 ppm) was detected above the low $\mathrm{SO}_{2}$ signal at this site. Peaks in $\mathrm{H}_{2} \mathrm{~S}$ data corresponded with those of $\mathrm{CO}_{2}$ on a number of occasions (Figure 4). The correlation between the $\mathrm{CO}_{2}$ and $\mathrm{H}_{2} \mathrm{~S}$ data was weak due in part to the poor resolution; the molar ratio of background corrected $\mathrm{CO}_{2} / \mathrm{H}_{2} \mathrm{~S}$ based on 1-min averages was between 0.3 and 35 (mean $14 \pm 8$ ).

[38] The composition of gases released at a $\mathrm{CO}_{2}$-rich fumarole on Masaya close to Nindiri crater (Figure 1b) was also investigated (Figure 5). The $\mathrm{CO}_{2}$ concentrations measured were between 450 and 5000 ppm while GEM varied between 11 and $219 \mathrm{ng} \mathrm{m}^{-3}$. The $\mathrm{CO}_{2}$ and GEM emissions correlated well $\left(\mathrm{r}^{2}=0.85\right)$ with a molar $\mathrm{GEM} / \mathrm{CO}_{2}$ ratio of $4.3 \pm 0.3 \times 10^{-9}$ (mass ratio $1.9 \pm 0.1 \times 10^{-8}$ ).

[39] The composition of gases of the low-temperature fumaroles at Cerro Comalito (CC, Figure 1b) was also studied (Figure 6). These fumaroles are situated further away from Masaya's main vent, are dominated by steam and diffuse $\mathrm{CO}_{2}$ emissions, and have a slightly lower temperature $\left(\sim 70-85^{\circ} \mathrm{C}\right)$ than those at Nindiri, (100$150^{\circ} \mathrm{C}$ [Gemmell, 1987]). Lower GEM concentrations, between 6.7 and $36.2 \mathrm{ng} \mathrm{m}^{-3}$, were measured at this location. $\mathrm{Hg}$ concentrations showed good agreement with both humidity and $\mathrm{CO}_{2}$. The molar ratio of $\mathrm{GEM} / \mathrm{CO}_{2}$ at Cerro Comalito was $4.0 \pm 0.2 \times 10^{-9}\left(\mathrm{r}^{2}=0.79\right.$; mass ratio $\left.1.8 \pm 0.1 \times 10^{-8}\right)$, similar to the ratio at the Nindiri fumarole despite the differences in volatile mercury concentration range.

[40] These results are similar to those observed in studies of fumaroles elsewhere. Engle et al. [2006] measured the 

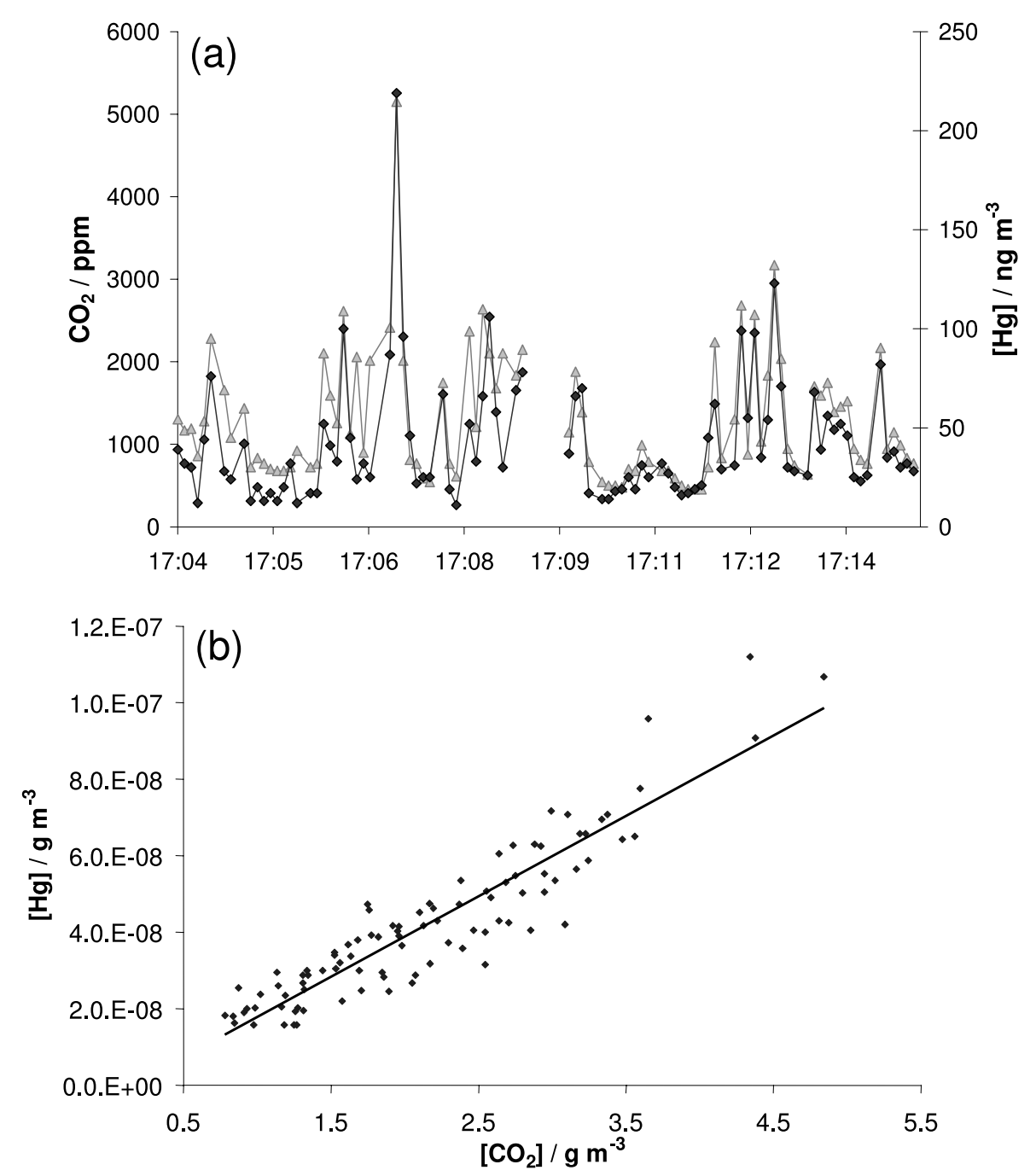

Figure 5. Measurements at a fumarole near Nindiri Crater, Masaya, 3 March 2006. Values are shown as $30 \mathrm{~s}$ averages. (a) GEM (black) and $\mathrm{CO}_{2}$ (gray) concentrations, (b) $[\mathrm{GEM}]$ plotted against $\left[\mathrm{CO}_{2}\right]$ as mass values.

$\mathrm{Hg} / \mathrm{CO}_{2}$ ratios in three hydrothermal systems in western United States with temperatures $85-95^{\circ} \mathrm{C}$ and a presence of $\mathrm{H}_{2} \mathrm{~S}$. These ratios bracketed those measured at Masaya's fumaroles with lower molar ratios at a fumarole and frying pan lake at Yellowstone caldera $\left(1.6\right.$ to $\left.2.6 \times 10^{-9}\right)$ and higher values in emissions of Mt Lassen's fumaroles (Cascades, USA) $\left(0.2\right.$ to $\left.2.2 \times 10^{-7}\right)$. Measurements at a higher temperature $\left(\sim 250^{\circ} \mathrm{C}\right)$ fumarole at La Fossa Crater, Vulcano with the same Lumex $/ \mathrm{CO}_{2}$ sensor set up found a $\mathrm{GEM} / \mathrm{CO}_{2}$ mass ratio of $6.0 \pm 0.3 \times 10^{-8}$ [Aiuppa et al., 2007]. Measurements made with this equipment at low temperature $\left(\sim 100^{\circ} \mathrm{C}\right)$ fumaroles at Tatun volcanic group, northern Taiwan, found a greater variation of $\mathrm{Hg} / \mathrm{CO}_{2}$ mass ratios $\left(4-40 \times 10^{-8}\right)$ than was observed at Masaya's fumaroles (M. L. Witt et al., submitted manuscript 2008).

[41] While it is possible that the $\mathrm{Hg}$ concentrations obtained here with the Lumex underestimate GEM, due to the difficulties discussed earlier (section 3.7), the good correlation between the GEM and $\mathrm{CO}_{2}$ data gives some confidence in the Lumex's ability to detect changes in Hg. At the Nindiri fumarole the $\mathrm{GEM} / \mathrm{CO}_{2}$ mass ratio varied over the 10 min sampling period at the fumarole between $8.5 \times 10^{-9}$ and $1.38 \times 10^{-7}$ (Figure $7 \mathrm{a}$ ). The mean $\mathrm{Hg} / \mathrm{CO}_{2}$ ratio based on one minute averages was $3.1 \pm 1.0 \times 10^{-8}$. The high GEM/ $/ \mathrm{CO}_{2}$ ratio did not always correspond with the high GEM concentrations. During this sampling period at the Nindiri fumarole, some $\mathrm{SO}_{2}$ was detected (up to $30 \mathrm{ppm}$ ), which may indicate an influence from the gases emitted by the main vent. The variation in the $\mathrm{Hg} / \mathrm{CO}_{2}$ ratios recorded at Nindiri fumarole could reflect a difference between the fumarolic and main vent $\mathrm{Hg} / \mathrm{CO}_{2}$. At Cerro Comalito, upwind and distant from the main vent, there was less variation observed in the $\mathrm{Hg} / \mathrm{CO}_{2}$ ratio (range $1.8-3.5 \times$ $10^{-8}$, mean $2.4 \pm 0.3 \times 10^{-8}$ Figure $7 \mathrm{~b}$ ), consistent with steady state degassing of a low temperature fumarole system, with minimal influence from the main vent gases.

\subsection{Mercury Fluxes From Masaya}

[42] Assuming that the composition of the fumarole gases is representative of the soil gas in this area, the low-temperature GEM flux from Masaya can be estimated from the diffuse $\mathrm{CO}_{2}$ soil flux of the region of 20 tons $\mathrm{d}^{-1}$ [Lewicki et 

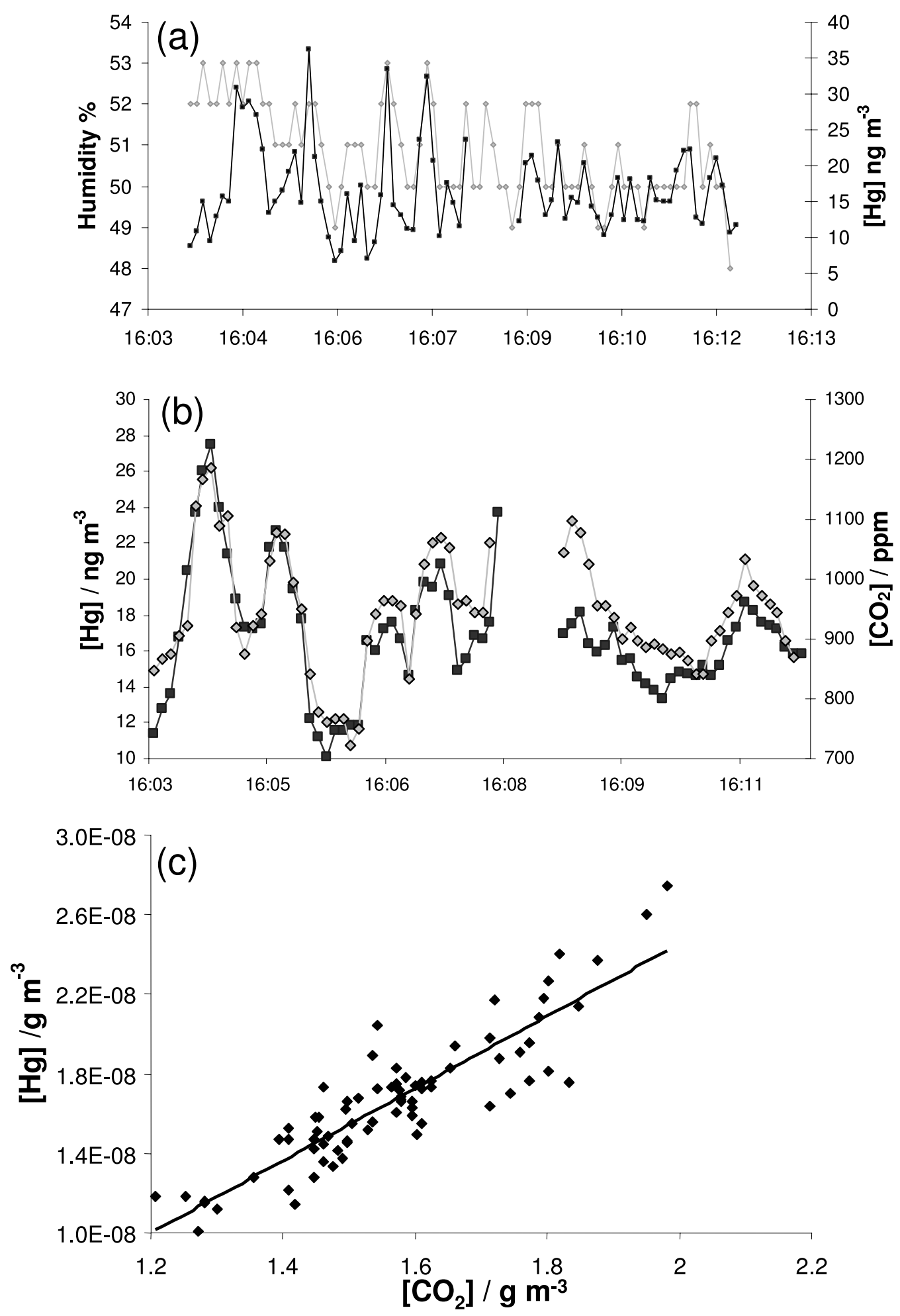

Figure 6. Measurements at Cerro Comalito, 6 March 2006. Values are shown as $30 \mathrm{~s}$ averages. (a) Humidity (light gray) and GEM (black) concentration in gases, (b) GEM (black) and $\mathrm{CO}_{2}$ (gray) concentrations, (c) $[\mathrm{GEM}]$ plotted against $\left[\mathrm{CO}_{2}\right]$ as mass values.

al., 2003]. This yields a low-temperature GEM flux from Masaya of $0.4 \mathrm{~g} \mathrm{GEM} \mathrm{d}^{-1}\left(55 \mu \mathrm{g} \mathrm{GEM} \mathrm{m}^{-2} \mathrm{~d}^{-1}\right)$. This is considerably lower than the TGM flux we estimate from Masaya's main vent (section 3.8). However, the lowtemperature Hg flux estimated here for Masaya is elevated above the background soil fluxes observed at unpolluted sites $\left(<2 \mu \mathrm{g} \mathrm{m}^{-2} \mathrm{~d}^{-1}\right.$ [García-Sánchez et al., 2006, and references therein]). The diffuse GEM flux per unit area that we estimate for Masaya is comparable to that estimated for two dormant volcanoes in El Salvador: at 

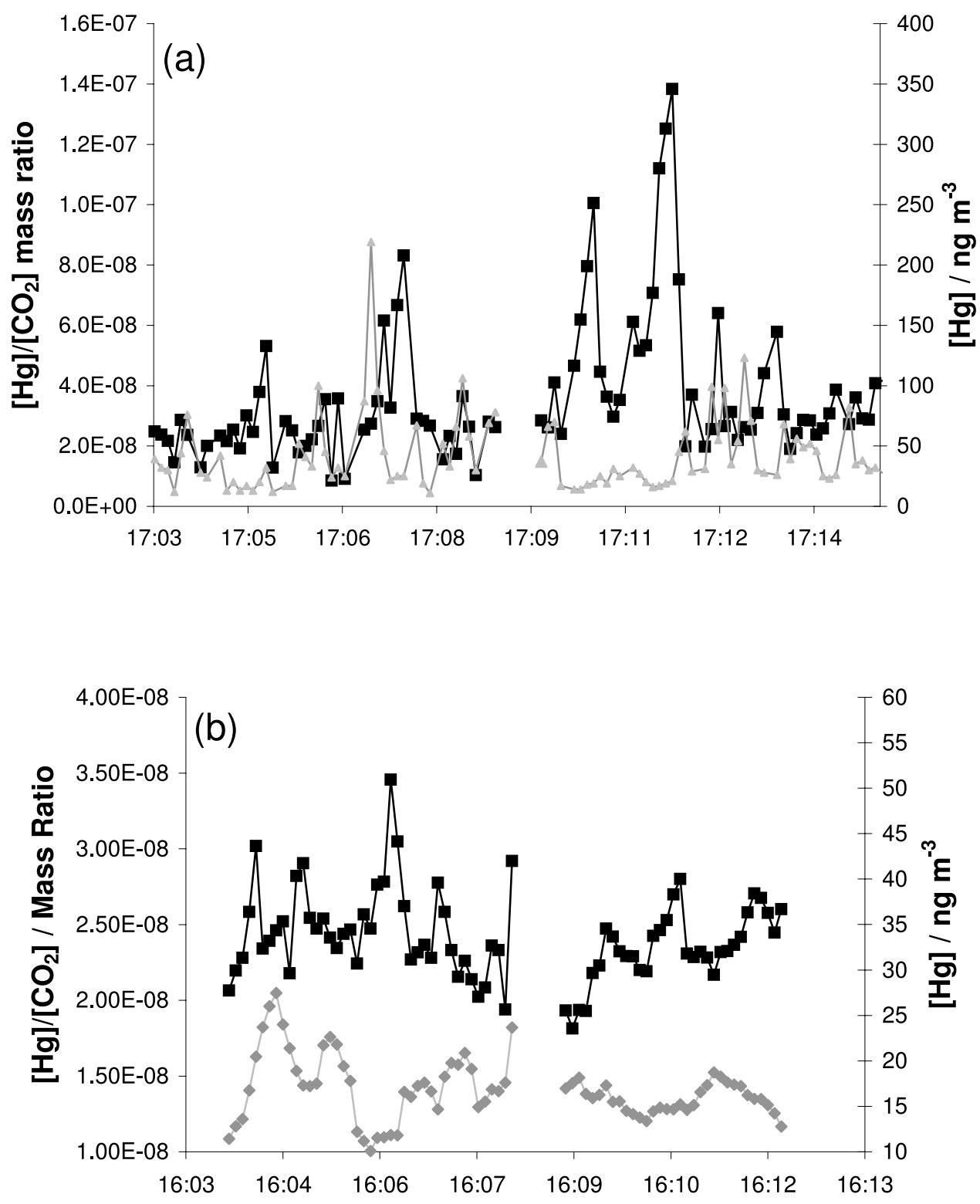

Figure 7. GEM concentrations (gray) and $\mathrm{GEM} / \mathrm{CO}_{2}$ ratios (black) measured spectrophotometrically (a) at a fumarole near Nindiri Crater, Masaya, 3 March 2006 and (b) at Cerro Comalito, 6 March 2006. Data plotted as $30 \mathrm{~s}$ averages.

Ilopango caldera, Lopez et al. [2004] measured soil gas $\mathrm{Hg}$ and $\mathrm{CO}_{2}$ and, from their distribution maps, we estimate that the $\mathrm{Hg}$ flux from one small anomaly ("F") is $\sim 10 \mu \mathrm{g} \mathrm{m}^{-2} \mathrm{~d}^{-1}$. From similar data for San Miguel volcano [Cartagena et al., 2004], we estimate a GEM flux of $35 \mu \mathrm{g} \mathrm{m}^{-2} \mathrm{~d}^{-1}$ for one anomaly ("M"). The Hg flux estimated for thermal sites at Lassen volcanic center was $6.5 \mu \mathrm{g} \mathrm{m}^{-2} \mathrm{~d}^{-1}$ and at acidic thermal sites at Yellowstone Caldera $3.3 \mu \mathrm{g} \mathrm{m}^{-2} \mathrm{~d}^{-1}$ [Engle et al., 2006]. These values were based on measurements with dynamic flux chambers and the thermally active areas showed the greatest variability in $\mathrm{Hg}$ fluxes.

[43] The concentration of $\mathrm{Hg}_{(\mathrm{p})}$ at Masaya's crater rim is estimated as $8 \mathrm{ng} \mathrm{m}^{-3}$. Using the average annual deposition velocity of $\mathrm{Hg}_{(\mathrm{p})}$ estimated by Shannon and Voldner [1995] as $0.17 \mathrm{~cm} \mathrm{~s}^{-1}$, a dry deposition flux of
$49 \mathrm{ng} \mathrm{m}^{-2} \mathrm{~h}^{-1}$ is obtained. The RGM concentration at Masaya of $2 \mathrm{ng} \mathrm{m}^{-3}$ with a RGM deposition velocity of $1 \mathrm{~cm} \mathrm{~s}^{-1}$ [Shannon and Voldner, 1995] would yield a dry deposition flux of $72 \mathrm{ng} \mathrm{m}^{-2} \mathrm{~h}^{-1}$. Although $\mathrm{Hg}$ concentrations are expected to dilute rapidly upon transport downwind, this represents a large input above background levels. Crater rim deposition fluxes are of a magnitude similar to those seen close to polluted urban and industrial areas (e.g., Detroit, 5-25 ng $\mathrm{Hg}_{(\mathrm{p})} \mathrm{m}^{-2} \mathrm{~h}^{-1}$ [Pirrone et al., 1995] or Tokyo, $1 \mathrm{ng} \mathrm{Hg} \mathrm{m}{ }^{-2} \mathrm{~h}^{-1}$ [Sakata and Marumoto, 2004]. In addition, wet deposition of trace metals is generally 3-5 times greater than dry deposition [Duce et al., 1991]. This suggests that Masaya is an important source of mercury to the immediate area downwind of the plume, delivering mercury far in excess of background unpolluted deposition fluxes. 
[44] Our measurements provide the first estimate of the TGM flux from Masaya. The $\mathrm{Hg} / \mathrm{SO}_{2}$ mass ratio determined at Masaya $\left(2 \times 10^{-5}\right)$ is within the range of values observed at other volcanoes $\left(10^{-6}-10^{-4}\right.$ [Aiuppa et al., 2007; Bagnato et al., 2007; Bichler et al., 1995; DeDuerwarder et al., 1982; Phelan et al., 1982; Siegel and Siegel, 1984; Varekamp and Buseck, 1981]) and leads to an annual flux of $\mathrm{Hg}$ to the atmosphere from Masaya volcano of $7.2 \mathrm{Mg} \mathrm{a}^{-1}$ (Table 3). This is an important regional flux, comparable in magnitude to the annual emissions of coal $\left(6.2 \mathrm{Mg} \mathrm{a}^{-1}\right)$, wood combustion (8.2 $\left.\mathrm{Mg} \mathrm{a}^{-1}\right)$, and oil combustion $\left(12.1 \mathrm{Mg} \mathrm{a}^{-1}\right)$ from South and Central America (1992 data) [Pirrone et al., 1996].

[45] Previous estimates of the global nonexplosive volcanic $\mathrm{Hg}$ flux have used $\mathrm{Hg} / \mathrm{SO}_{2}$ ratios between $10^{-7}$ and $10^{-5}$ [Ferrara et al., 2000; Nriagu and Becker, 2003; Nriagu, 1989; Varekamp and Buseck, 1986]. The $\mathrm{Hg} / \mathrm{SO}_{2}$ ratio at Masaya is toward the upper end of this range and, if representative of similar volcanoes, suggests that volcanic mercury emissions from the degassing of basaltic magma is an important component of the global atmospheric $\mathrm{Hg}$ budget. Given a time-averaged $\mathrm{SO}_{2}$ flux from high-temperature volcanism of ca. $3.7 \mathrm{Tg}\left(\mathrm{SO}_{2}\right) \mathrm{a}^{-1}$ [Andres and Kasgnoc, 1998; Pyle and Mather, 2003], then the corresponding global volcanic $\mathrm{Hg}$ flux, from degassing basaltic volcanoes, could be of the order of $74 \mathrm{Mg} \mathrm{a}^{-1}$. Of course, this is an empirical result, and much more work remains to be done to understand the roles of magma composition, eruptive temperature, and volcanic gas composition in determining the $\mathrm{SO}_{2}-\mathrm{Hg}-\mathrm{CO}_{2}$ systematics of magmatic gases.

\section{Summary}

[46] We have made the first measurements of the volcanic degassing flux of mercury from Masaya volcano, Nicaragua, using both portable gas sensors and gold traps. $\mathrm{Hg} / \mathrm{SO}_{2}$ mass ratios measured in real-time with a Lumex ranged from $1.1 \times 10^{-7}$ to $3.5 \times 10^{-5}$, with a mean $\mathrm{Hg} / \mathrm{SO}_{2}$ ratio of $2 \times 10^{-5}$. Total gaseous mercury (TGM) concentrations measured by gold trap ranged from 100 to $225 \mathrm{ng} \mathrm{m}^{-3}$. Reactive gaseous mercury accounted for $1 \%$ of TGM, while particulate mercury was $5 \%$ of the TGM. From these data, we estimate that the average high-temperature $\mathrm{Hg}$ flux from Masaya's main vent (Santiago Crater) is $\sim 7.2 \mathrm{Mg} \mathrm{a}^{-1}$. This is comparable in magnitude to mercury emissions from coal or wood combustion Central and South America [Pirrone et al. 1996]. At Masaya's low temperature fumaroles, $\mathrm{Hg} / \mathrm{CO}_{2}$ mass ratios were consistently around $2 \times 10^{-8}$, lower than observed in the magmatic gases of the main vent $\left(\mathrm{Hg} / \mathrm{CO}_{2}\right.$ $\sim 10^{-7}$ ). Low-temperature $\mathrm{Hg}$ fluxes from Masaya's fumaroles are insignificant $\left(\sim 150 \mathrm{~g} \mathrm{a}^{-1}\right)$; consistent with the dominance of high-temperature degassing fluxes for other volatile species at Masaya (e.g., $\mathrm{SO}_{2}, \mathrm{CO}_{2}$ ).

[47] Ratios of $\mathrm{S}, \mathrm{C}, \mathrm{Cl}, \mathrm{Br}$, and I were also measured at Masaya and Telica volcanoes. $\mathrm{CO}_{2} / \mathrm{SO}_{2}$ ratios at Masaya ranged from 2.8 to 3.9 , comparable to previously published values. At Masaya, molar $\mathrm{Br} / \mathrm{SO}_{2}$ was $3 \times 10^{-4}$ and $\mathrm{I} / \mathrm{SO}_{2}$ was $2 \times 10^{-5}$ suggesting time-averaged fluxes of $0.2-0.5 \mathrm{Mg} \mathrm{HBr} \mathrm{d}^{-1}$ and $0.02-0.05 \mathrm{Mg} \mathrm{HI} \mathrm{d}^{-1}$. At Telica the $\mathrm{Br} / \mathrm{SO}_{2}$ ratio was also $3 \times 10^{-4}$ and the $\mathrm{I} / \mathrm{SO}_{2}$ ratio was $5.8 \times 10^{-5}$, with corresponding fluxes of $0.2 \mathrm{Mg}$
$\mathrm{HBr} \mathrm{d}^{-1}$ and $0.06 \mathrm{Mg} \mathrm{HI} \mathrm{d}^{-1}$. Gases at both volcanoes are enriched in I relative to $\mathrm{Br}$ and $\mathrm{Cl}$, compared to gases from volcanoes elsewhere.

[48] Acknowledgments. We thank A. Franco and others at Università di Palermo for their help and support during field preparation and subsequent analysis and Wilfried Strauch, Manuel Traña, others at INETER Managua, and the director and staff at Masaya National Park, Nicaragua for their help and logistical support during fieldwork. We thank Paul Taylor of the University of Cambridge, Department of Earth Sciences for construction of the gas sensor system. This work was funded by NERC grant NE/ C511180/1/. TAM acknowledges financial support from the Royal Society. The authors thank Paolo Fulignati and an anonymous reviewer for their thoughtful comments.

\section{References}

Aiuppa, A., G. Dongarrà, M. Valenza, C. Federico, and G. Pecoraino (2003), Degassing of trace volatile metals during the 2001 eruption of Etna, in Volcanism and the Earth's Atmosphere, Geophys. Monogr. Ser, vol. 139, edited by A. Robock and C. Oppenheimer, pp. 41-54, AGU, Washington, D. C.

Aiuppa, A., C. Federico, A. Franco, G. Giudice, S. Gurrieri, S. Inguaggiato, M. Liuzzo, A. J. S. McGonigle, and M. Valenza (2005a), Emission of bromine and iodine from Mount Etna volcano, Geochem. Geophys. Geosyst., 6, Q08008, doi:10.1029/2005GC000965.

Aiuppa, A., C. Federico, G. Giudice, and S. Gurrieri (2005b), Chemical mapping of a fumarolic field: La Fossa Crater, Volcano Island (Aeolian Islands, Italy), Geophys. Res. Lett., 32, L13309, doi:10.1029/ 2005GL023207.

Aiuppa, A., E. Bagnato, M. L. I. Witt, T. A. Mather, F. Parello, D. M. Pyle, and R. S. Martin (2007), Real-time simultaneous detection of volcanic $\mathrm{Hg}$ and $\mathrm{SO}_{2}$ at La Fossa Crater, Vulcano (Aeolian Islands, Sicily), Geophys. Res. Lett., 34, L21307, doi:10.1029/2007GL030762.

Allard, P., A. Aiuppa, H. Loyer, F. Carrot, A. Gaudry, G. Pinte, A. Michel, and G. Dongarra (2000), Acid gas and metal emission rates during longlived basalt degassing at Stromboli volcano, Geophys. Res. Lett., 27, 1207-1210, doi:10.1029/1999GL008413.

Allen, A. G., T. A. Mather, A. J. S. McGonigle, A. Aiuppa, P. Delmelle, B. Davison, N. Bobrowski, C. Oppenheimer, D. M. Pyle, and S. Inguaggiato (2006), Sources, size distribution, and downwind grounding of aerosols from Mount Etna, J. Geophys. Res., 111, D10302, doi:10.1029/ 2005JD006015

Andres, R. J., and A. D. Kasgnoc (1998), A time-averaged inventory of subaerial volcanic sulfur emissions, J. Geophys. Res., 103, 25,25125,261, doi:10.1029/98JD02091.

Aspmo, K., et al. (2005), Measurements of atmospheric mercury species during an international study of mercury depletion events at Ny-Alesund, Svalbard, spring 2003. How reproducible are our present methods?, Atmos. Environ., 39, 7607-7619, doi:10.1016/j.atmosenv.2005.07.065.

Bagnato, E. (2007), Estimates of mercury emission rates in active volcanic systems, Ph.D. thesis, 152 pp., Univ. degli Studi di Palermo, Italy.

Bagnato, E., A. Aiuppa, F. Parello, S. Calabrese, W. D'Alessandro, T. A. Mather, A. J. S. McGonigle, D. M. Pyle, and I. Wängberg (2007), Degassing of gaseous (elemental and reactive) and particulate mercury from Mount Etna volcano (Southern Italy), Atmos. Environ., 41, 7377-7388, doi:10.1016/j.atmosenv.2007.05.060.

Bichler, M., K. Poljanc, and F. Sortino (1995), Determination and speciation of minor and trace elements in volcanic exhalations by NAA, J. Radioanalytical Nucl. Chem. A, 192, 183-194, doi:10.1007/ BF02041722.

Bloom, N. S. (1992), On the chemical form of mercury in edible fish and marine invertebrate tissue, Can. J. Fish. Aquat. Sci., 49, 1010-1017, doi:10.1139/f92-113.

Bureau, H., and N. Métrich (2003), An experimental study of bromine behaviour in water-saturated silicic melts, Geochim. Cosmochim. Acta, 67, 1689-1697, doi:10.1016/S0016-7037(02)01339-X.

Bureau, H., H. Keppler, and N. Métrich (2000), Volcanic degassing of bromine and iodine: Experimental fluid/melt partitioning data and applications to stratospheric chemistry, Earth Planet. Sci. Lett., 183, 51-60, doi:10.1016/S0012-821X(00)00258-2.

Burton, M. R., C. Oppenheimer, L. A. Horrocks, and P. W. Francis (2000), Remote sensing of $\mathrm{CO}_{2}$ and $\mathrm{H}_{2} \mathrm{O}$ emission rates from Masaya volcano, Nicaragua, Geology, 28, 915-918, doi:10.1130/0091-7613(2000) $28<915:$ RSOCAH $>2.0 . \mathrm{CO} ; 2$.

Caltabiano, T., M. Burton, S. Giammanco, P. Allard, N. Bruno, F. Murè, and R. Romano (2004), Volcanic gas emission from the summit craters and flanks of Mt. Etna, 1987-2000, in Mt. Etna: Volcano Laboratory, 
Geophys. Monogr. Ser, vol. 143, edited by A. Bonaccorso et al., pp. 111-128, AGU, Washington, D. C.

Cartagena, R., R. Olmos, D. L. López, T. Soriano, F. Barahona, P. A. Hernández, and N. M. Pérez (2004), Diffuse soil degassing of carbon dioxide, radon, and mercury at San Miguel volcano, El Salvador, in Natural Hazards in El Salvador, edited by W. I. Rose, et al., Geol. Soc. Am. Spec. Pap., 375, 203-212.

Crenshaw, W. B., S. N. Williams, and R. E. Stoiber (1982), Fault location by radon and mercury detection at an active volcano, Nature, 300 , 345-346, doi: $10.1038 / 300345 \mathrm{a} 0$.

DeDuerwarder, H., G. Decadt, and W. Baeyens (1982), Estimations of mercury fluxes emitted by Mt. Etna volcano, Bull. Volcanol., 45 , 191-196, doi:10.1007/BF02597729.

Delmelle, P., et al. (1999), Origin, effects of Masaya volcano's continued unrest probed in Nicaragua, Eos Trans. AGU, 80, 575-581.

Delmelle, P., J. Stix, P. J. Baxter, J. Garcia-Alvarez, and J. Barquero (2002), Atmospheric dispersion, environmental effects and potential health hazard associated with the low-altitude gas plume of Masaya volcano, Nicaragua, Bull. Volcanol., 64, 423-434, doi:10.1007/s00445-002 0221-6.

Draxler, R. R., and G. D. Rolph (2003), HYSPLIT (HYbrid Single-Particle Lagrangian Integrated Trajectory) model, NOAA Air Resour. Lab., Silver Spring, Md. (Available at http://www.arl.noaa.gov/ready/hysplit4.html).

Duce, R. A., et al. (1991), The atmospheric input of trace species to the world ocean, Global Biogeochem. Cycles, 5, 193-259, doi:10.1029/ 91GB01778.

Duffell, H. J., C. Oppenheimer, D. M. Pyle, B. Galle, A. J. S. McGonigle, and M. R. Burton (2003), Changes in gas composition prior to a minor explosive eruption at Masaya volcano, Nicaragua, J. Volcanol. Geotherm. Res., 126, 327-339, doi:10.1016/S0377-0273(03)00156-2.

Ebinghaus, R., et al. (1999), International field intercomparison measurements of atmospheric mercury species at Mace Head, Ireland, Atmos. Environ., 33, 3063-3073, doi:10.1016/S1352-2310(98)00119-8.

Egeberg, P. K., and G. R. Dickens (1999), Thermodynamic and pore water halogen constraints on gas hydrate distribution at ODP Site 997 (Blake Ridge), Chem. Geol., 153, 53-79, doi:10.1016/S0009-2541 (98)00152-1.

Engle, M. A., M. S. Gustin, F. Goff, D. A. Counce, C. J. Janik, D. Bergfeld, and J. J. Rytuba (2006), Atmospheric mercury emissions from substrates and fumaroles associated with three hydrothermal systems in the western United States, J. Geophys. Res., 111, D17304, doi:10.1029/ 2005JD006563

Ferrara, R., B. Mazzolai, E. Lanzillotta, E. Nucaro, and N. Pirrone (2000), Volcanoes as emission sources of atmospheric mercury in the Mediterranean basin, Sci. Total Environ., 259, 115-121, doi:10.1016/ S0048-9697(00)00558-1.

Fitzgerald, W. F., D. R. Engstrom, R. P. Mason, and E. A. Nater (1998), The case for atmospheric mercury contamination in remote areas, Environ Sci. Technol., 32, 1-7.

Fulignati, P., A. Sbrana, R. Clocchiatti, and W. Luperini (2006), Environmental impact of the acid fumarolic plume of a passively degassing volcano (Vulcano Island, Italy), Environ. Geol., 49, 1139-1155, doi:10.1007/s00254-005-0158-0.

García-Sánchez, A., F. Contreras, M. Adams, and F. Santos (2006), Atmospheric mercury emissions from polluted gold mining areas (Venezuela), Environ. Geochem. Health, 28, 529-540, doi:10.1007/ s10653-006-9049-x

Gemmell, J. B. (1987), Geochemistry of metallic trace elements in fumarolic condensates from Nicaraguan and Costa Rican volcanoes, J. Volcanol. Geotherm. Res., 33, 161-181, doi:10.1016/0377-0273(87)90059-X.

Gerlach, T. M. (2004), Volcanic sources of tropospheric ozone-depleting trace gases, Geochem. Geophys. Geosyst., 5, Q09007, doi:10.1029/ 2004GC000747.

Ghorishi, S. B., C. W. Lee, W. S. Jozewicz, and J. D. Kilgroe (2005), Effects of fly ash transition metal content and flue gas $\mathrm{HCl} / \mathrm{SO}_{2}$ ratio on mercury speciation in waste combustion, Environ. Eng. Sci., 22, 221-231, doi:10.1089/ees.2005.22.221.

Giammanco, S., M. Ottaviani, M. Valenza, E. Veschetti, E. Principio, G. Giammanco, and S. Pignato (1998), Major and trace elements geochemistry in the ground waters of a volcanic area: Mount Etna (Sicily, Italy), Water Res., 32, 19-30, doi:10.1016/S0043-1354(97)00198-X

Hinkley, T. K., P. J. Lamothe, S. A. Wilson, D. L. Finnegan, and T. M. Gerlach (1999), Metal emissions from Kilauea, and a suggested revision of the estimated worldwide metal output by quiescent degassing of volcanoes, Earth Planet. Sci. Lett., 170, 315-325, doi:10.1016/ S0012-821X(99)00103-X

Honda, F. (1970), Geochemical study of iodine in volcanic gases. II Behaviour of iodine in volcanic gases, Geochem. J., 3, 201-211.

Hurwitz, S., R. H. Mariner, U. Fehn, and G. T. Snyder (2005), Systematics of halogen elements and their radioisotopes in thermal springs of the
Cascade Range, Central Oregon, Western USA, Earth Planet. Sci. Lett., 235, 700-714, doi:10.1016/j.epsl.2005.04.029.

Jarrard, R. D. (2003), Subduction fluxes of water, carbon dioxide, chlorine, and potassium, Geochem. Geophys. Geosyst., 4(5), 8905, doi:10.1029/ 2002GC000392.

Jitaru, P., and F. Adams (2004), Toxicity, sources and biogeochemical cycle of mercury, J. Phys., 121, 185-193.

Johnson, L. H., R. Burgess, G. Turner, H. J. Milledge, and J. W. Harris (2000), Noble gas and halogen geochemistry of mantle fluids: Comparison of African and Canadian diamonds, Geochim. Cosmochim. Acta, 64 , 717-732, doi:10.1016/S0016-7037(99)00336-1.

Jonnalagadda, S. B., and P. Rao (1993), Toxicity, bioavailability and metal speciation, Comp. Biochem. Physiol. C Pharmacol. Toxicol. Endocrinol. 106, 585-595, doi:10.1016/0742-8413(93)90215-7.

Kim, K. H., V. K. Mishra, and S. Hong (2006), The rapid and continuous monitoring of gaseous elemental mercury (GEM) behaviour in ambient air, Atmos. Environ., 40, 3281-3293, doi:10.1016/j.atmosenv. 2006.01.046.

Landis, M. S., R. K. Stevens, F. Schaedlich, and E. M. Prestbo (2002), Development and characterization of an annular denuder methodology for the measurement of divalent inorganic reactive gaseous mercury in ambient air, Environ. Sci. Technol., 36, 3000-3009.

Lewicki, J. L., C. Connor, K. St.-Amand, J. Stix, and W. Spinner (2003), Self-potential, soil $\mathrm{CO}_{2}$ flux, and temperature on Masaya volcano, Nicaragua, Geophys. Res. Lett., 30(15), 1817, doi:10.1029/ 2003GL017731.

Lindberg, S. E., and W. J. Stratton (1998), Atmospheric mercury speciation: Concentrations and behavior of reactive gaseous mercury in ambient air, Environ. Sci. Technol., 32, 49-57.

Lindqvist, O., and H. Rodhe (1985), Atmospheric mercury - A review, Tellus, Ser. B, 37, 136-159.

Lopez, D. L., L. Ransom, N. M. Perez, P. A. Hernandez, and J. Monterrosa (2004), Dynamics of diffuse degassing at Ilopango Caldera, El Salvador, in Natural Hazards in El Salvador, edited by W. I. Rose et al., Geol. Soc. Am. Spec. Pap., 375, 191-202.

Lynam, M. M., and G. J. Keeler (2006), Source-receptor relationships for atmospheric mercury in urban Detroit, Michigan, Atmos. Environ., 40 3144-3155, doi:10.1016/j.atmosenv.2006.01.026.

Martin, J. B., J. M. Gieskes, M. Torres, and M. Kastner (1993), Bromine and iodine in Peru margin sediments and pore fluids: Implications for fluid origins, Geochim. Cosmochim. Acta, 57, 4377-4389, doi:10.1016/ 0016-7037(93)90489-J.

Martin, R. S., T. A. Mather, and D. M. Pyle (2006), High-temperature mixtures of magmatic and atmospheric gases, Geochem. Geophys. Geosyst., 7, Q04006, doi:10.1029/2005GC001186.

Mason, R. P., J. R. Reinfelder, and F. M. M. Morel (1995), Bioaccumulation of mercury and methylmercury, Water Air Soil Pollut., 80, 915-921, doi:10.1007/BF01189744

Mather, T. A., D. M. Pyle, and C. Oppenheimer (2003), Tropospheric volcanic aerosol, in Volcanism and the Earth's Atmosphere, Geophys. Monograph Ser, vol. 139, edited by A. Robock and C. Oppenheimer, pp. 189-212, AGU, Washington, D. C.

Mather, T. A., D. M. Pyle, and A. G. Allen (2004), Volcanic source for fixed nitrogen in the early Earth's atmosphere, Geology, 32(10), 905-908.

Mather, T. A., D. M. Pyle, V. I. Tsanev, A. J. S. McGonigle, C. Oppenheimer, and A. G. Allen (2006), A reassessment of current volcanic emissions from the Central American arc with specific examples from Nicaragua, J. Volcanol. Geotherm. Res., 149, 297-311, doi:10.1016/j.jvolgeores. 2005.07.021.

Morel, F. M. M., A. M. L. Kraepiel, and M. Amyot (1998), The chemical cycle and bioaccumulation of mercury, Annu. Rev. Ecol. Syst., 29, $543-$ 566, doi:10.1146/annurev.ecolsys.29.1.543

Munthe, J., et al. (2001), Intercomparison of methods for sampling and analysis of atmospheric mercury species, Atmos. Environ., 35, $3007-$ 3017, doi:10.1016/S1352-2310(01)00104-2.

Nadeau, P. A., and G. Williams-Jones (2008), Apparent downwind depletion of volcanic $\mathrm{SO}_{2}$ flux: Lessons from Masaya volcano, Nicaragua, Bull. Volcanol., in press.

Newsom, H. E. (1995), Composition of the solar system, planets, meteorites, and major terrestrial reservoirs, in A Handbook of Physical Constants: Global Earth Physics, Ref. Shelf, vol. 1, edited by T. J. Ahrens, pp. 159-189, AGU, Washington, D. C.

Nozaki, Y. (1997), A fresh look at element distribution in the North Pacific Ocean, Eos Trans. AGU, 78(21), 221.

Nriagu, J. O. (1989), A global assessment of natural sources of atmospheric trace metals, Nature, 338, 47-49, doi:10.1038/338047a0.

Nriagu, J., and C. Becker (2003), Volcanic emissions of mercury to the atmosphere: global and regional inventories, Sci. Total Environ., 304, 3-12, doi:10.1016/S0048-9697(02)00552-1. 
Pacyna, E. G., and J. M. Pacyna (2002), Global emission of mercury from anthropogenic sources in 1995, Water Air Soil Pollut., 137, 149-165, doi:10.1023/A:1015502430561.

Phelan, J. M., D. L. Finnegan, D. S. Ballantine, and W. H. Zoller (1982), Airborne aerosol measurements in the quiescent plume of Mount St. Helens: September, 1980, Geophys. Res. Lett., 9, 1093-1096, doi:10.1029/GL009i009p01093.

Pirrone, N., G. Glinsorn, and G. J. Keeler (1995), Ambient levels and dry deposition fluxes of mercury to Lakes Huron, Erie and St. Clair, Water Air Soil Pollut., 80, 179-188, doi:10.1007/BF01189666.

Pirrone, N., G. J. Keeler, and J. O. Nriagu (1996), Regional differences in worldwide emissions of mercury to the atmosphere, Atmos. Environ., 30 2981-2987, doi:10.1016/1352-2310(95)00498-X.

Plank, T., and C. H. Langmuir (1998), The chemical composition of subducting sediment and its consequences for the crust and mantle, Chem. Geol., 145, 325-394, doi:10.1016/S0009-2541(97)00150-2.

Poissant, L., M. Pilote, C. Beauvais, P. Constant, and H. H. Zhang (2005), A year of continuous measurements of three atmospheric mercury species (GEM, RGM and Hg-p) in southern Quebec, Canada, Atmos. Environ., 39, 1275-1287, doi:10.1016/j.atmosenv.2004.11.007.

Pyle, D. M., and T. A. Mather (2003), The importance of volcanic emissions for the global atmospheric mercury cycle, Atmos. Environ., 37 5115-5124, doi:10.1016/j.atmosenv.2003.07.011.

Roche, O., B. van Wyk de Vries, and T. H. Druitt (2001), Sub-surface structures and collapse mechanisms of summit pit craters, J. Volcanol. Geotherm. Res., 105, 1-18, doi:10.1016/S0377-0273(00)00248-1.

Rymer, H., B. V. de Vries, J. Stix, and G. Williams-Jones (1998), Pit crater structure and processes governing persistent activity at Masaya Volcano, Nicaragua, Bull. Volcanol., 59, 345-355, doi:10.1007/s004450050196.

Sakata, M., and K. Marumoto (2004), Dry deposition fluxes and deposition velocities of trace metals in the Tokyo metropolitan area measured with a water surface sampler, Environ. Sci. Technol., 38, 2190-2197.

Schroeder, W. H., and J. Munthe (1998), Atmospheric mercury - An overview, Atmos. Environ., 32, 809-822, doi:10.1016/S1352-2310 (97)00293-8.

Schroeder, W. H., G. Keeler, H. Kock, P. Roussel, D. Schneeberger, and F. Schaedlich (1995), International field intercomparison of atmospheric mercury measurement methods, Water Air Soil Pollut., 80, 611-680, doi:10.1007/BF01189713.

Shannon, J. D., and E. C. Voldner (1995), Modeling atmospheric concentrations of mercury and deposition to the great lakes, Atmos. Environ., 29, 1649-1661, doi:10.1016/1352-2310(95)00075-A.

Shinohara, H. (2005), A new technique to estimate volcanic gas composition: plume measurements with a portable multi-sensor system, J. Volcanol. Geotherm. Res., 143, 319-333, doi:10.1016/j.jvolgeores. 2004.12.004.
Sholupov, S. E., and A. A. Ganeyev (1995), Zeeman atomic absorption spectrometry using high frequency modulated light polarization, Spectrochim. Acta Part B: Atomic Spectrosc., 50, 1227-1236, doi:10.1016/ 0584-8547(95)01316-7.

Siegel, S. M., and B. Z. Siegel (1984), First estimate of annual mercury flux at the Kilauea main vent, Nature, 309, 146-147, doi:10.1038/309146a0.

Slemr, F., G. Schuster, and W. Seiler (1985), Distribution, speciation, and budget of atmospheric mercury, J. Atmos. Chem., 3, 407-434, doi:10.1007/BF00053870.

Snyder, G. T., and U. Fehn (2002), Origin of iodine in volcanic fluids: ${ }^{129} \mathrm{I}$ results from the Central American Volcanic Arc, Geochim. Cosmochim. Acta, 66, 3827-3838, doi:10.1016/S0016-7037(02)00825-6.

Stoiber, R. E., S. N. Williams, and B. J. Huebert (1986), Sulfur and halogen gases at Masaya caldera complex, Nicaragua: Total flux and variations with time, J. Geophys. Res., 91, 12,215-12,231, doi:10.1029/ JB091iB12p12215.

Ullrich, S. M., T. W. Tanton, and S. A. Abdrashitova (2001), Mercury in the aquatic environment: A review of factors affecting methylation, Crit. Rev. Environ. Sci. Technol., 31, 241-293, doi:10.1080/20016491089226.

Valente, R. J., C. Shea, K. L. Humes, and R. L. Tanner (2007), Atmospheric mercury in the Great Smoky Mountains compared to regional and global levels, Atmos. Environ., 41, 1861-1873, doi:10.1016/j.atmosenv. 2006.10.054.

Varekamp, J. C., and P. R. Buseck (1981), Mercury emissions from Mount St. Helens during September 1980, Nature, 293, 555-556, doi:10.1038/ $293555 \mathrm{a} 0$

Varekamp, J. C., and P. R. Buseck (1986), Global mercury flux from volcanic and geothermal sources, Appl. Geochem., 1, 65-73, doi:10.1016/0883-2927(86)90038-7.

Varrica, D., A. Aiuppa, and G. Dongarra (2000), Volcanic and anthropogenic contribution to heavy metal content in lichens from Mt. Etna and Vulcano island (Sicily), Environ. Pollut., 108, 153-162, doi:10.1016/ S0269-7491(99)00246-8.

Watt, S. F. L., D. M. Pyle, T. A. Mather, J. A. Day, and A. Aiuppa (2007), The use of tree rings and foliage as an archive of volcanogenic cation deposition, Environ. Pollut., 148, 48-61, doi:10.1016/j.envpol. 2006.11.007.

A. Aiuppa and E. Bagnato, Dipartimento di Chimica e Fisica della Terra ed Applicazioni alle Georisorse e ai Rischi Naturali, Università di Palermo, Palermo, I-90123 Italy.

T. A. Mather, D. M. Pyle, and M. L. I. Witt, Department of Earth Sciences, University of Oxford, Parks Road, Oxford OX1 3PR, UK. (melanie.witt@earth.ox.ac.uk)

V. I. Tsanev, Department of Geography, University of Cambridge, Downing Place, Cambridge CB2 3EN, UK. 